Review

\title{
Prospects of Curcumin Nanoformulations in Cancer Management
}

\author{
Hilda Amekyeh ${ }^{1}$, , Enas Alkhader ${ }^{2}$, Rayan Sabra ${ }^{3}$ and Nashiru Billa ${ }^{4, *(\mathbb{C})}$ \\ 1 Department of Pharmaceutics, School of Pharmacy, University of Health and Allied Sciences, \\ Ho PMB 31, Ghana; hamekyeh@uhas.edu.gh \\ 2 Faculty of Pharmacy, Middle East University, Amman 11831, Jordan; ealkhader@meu.edu.jo \\ 3 Department of Pharmaceutical Sciences, University of Connecticut, Storrs, CT 06269, USA; \\ rayan.sabra@uconn.edu \\ 4 Pharmaceutical Sciences Department, College of Pharmacy, QU Health, Qatar University, \\ Doha P.O. Box 2713, Qatar \\ * Correspondence: nbilla@qu.edu.qa
}

Citation: Amekyeh, H.; Alkhader, E.; Sabra, R.; Billa, N. Prospects of

Curcumin Nanoformulations in

Cancer Management. Molecules 2022, 27, 361. https://doi.org/10.3390/ molecules27020361

Academic Editor: Chiara Porro

Received: 16 November 2021

Accepted: 3 January 2022

Published: 7 January 2022

Publisher's Note: MDPI stays neutral with regard to jurisdictional claims in published maps and institutional affiliations.

Copyright: (C) 2022 by the authors. Licensee MDPI, Basel, Switzerland. This article is an open access article distributed under the terms and conditions of the Creative Commons Attribution (CC BY) license (https:// creativecommons.org/licenses/by/ $4.0 /)$.

\begin{abstract}
There is increasing interest in the use of natural compounds with beneficial pharmacological effects for managing diseases. Curcumin (CUR) is a phytochemical that is reportedly effective against some cancers through its ability to regulate signaling pathways and protein expression in cancer development and progression. Unfortunately, its use is limited due to its hydrophobicity, low bioavailability, chemical instability, photodegradation, and fast metabolism. Nanoparticles (NPs) are drug delivery systems that can increase the bioavailability of hydrophobic drugs and improve drug targeting to cancer cells via different mechanisms and formulation techniques. In this review, we have discussed various CUR-NPs that have been evaluated for their potential use in treating cancers. Formulations reviewed include lipid, gold, zinc oxide, magnetic, polymeric, and silica NPs, as well as micelles, dendrimers, nanogels, cyclodextrin complexes, and liposomes, with an emphasis on their formulation and characteristics. CUR incorporation into the NPs enhanced its pharmaceutical and therapeutic significance with respect to solubility, absorption, bioavailability, stability, plasma half-life, targeted delivery, and anticancer effect. Our review shows that several CUR-NPs have promising anticancer activity; however, clinical reports on them are limited. We believe that clinical trials must be conducted on CUR-NPs to ensure their effective translation into clinical applications.
\end{abstract}

Keywords: curcumin; cancer; nanoparticles; drug delivery; chemotherapy; bioavailability

\section{Introduction}

According to Global Cancer Incidence, Mortality and Prevalence (GLOBOCAN) 2020, over 19.3 million new cancer cases were diagnosed globally in 2020, with nearly 10.0 million deaths attributed to this statistic [1]. Specifically, lung cancer is the prominent cause of death from cancer in men, while breast and cervical cancers are the primary causes of cancer death in women. Cancer originates when cells in the body start to grow out of control and typically develop slowly over several years. Thus, cells in almost any part of the body can potentially develop into a cancer and can spread to other areas of the body.

The prognosis and treatment options for cancer mainly depend on the stage of the cancer, tumor recurrence, and the patient's general health. The four prevalent cancer treatment procedures are surgery, chemotherapy, radiotherapy, and targeted therapy [2]. Surgery is the first therapeutic approach and primary procedure. Usually, surgery is combined with chemotherapy and/or radiation therapy to avoid residual tumor recurrence. In radiotherapy, energy and X-rays produced by a linear accelerator are employed to destroy cellular DNA and inhibit cell proliferation [3]. On the other hand, chemotherapy relies on cytotoxic drugs to inhibit the growth of cancer cells and kill them [4]. Chemotherapy is either administered before surgery to shrink tumors, or after surgery as adjuvant chemotherapy. Due to 
the limited efficacy of non-selective chemotherapeutic drugs, targeted therapy has evolved as a rational option. In targeted therapy, drugs are targeted to specific receptors present on cancer cells or in structures related to cancer growth, such as blood vessels. Additionally, cancer cell proliferation and metastasis are blocked via the inhibition of specific mediators such as epidermal growth factors (EGFs) [5]. However, the effectiveness of targeted therapy depends on the release of the therapeutic agent at the cancer target site, as well as minimizing off-target side effects to normal tissues [6].

Regardless of the advanced innovations in cancer therapy, treatment remains arduous. For instance, surgery is affiliated with detrimental harm to adjacent organs and tissues, discomfort, infections, and relapse [7-9]. While chemotherapy, the typical cancer treatment option, whether administered as a neoadjuvant, adjuvant, or sole therapy, demonstrates severe side effects, involving fatigue, sores in the mouth and throat, nausea, vomiting, and blood disorders [10-12]. Radiation therapy also manifests a wide range of side effects akin to skin changes, fatigue, and diarrhea, among others, that disturb the well-being of the patients. Even though targeted therapy has emerged as an approach to conquer the lack of specificity in conventional chemotherapy, there are potential risks and challenges associated with this novel strategy. For example, some cancer cell types develop resistance to drugs over the treatment course, thereby rendering the targeted therapy ineffective by driving the drug out of the cancer cells and decreasing intracellular drug concentration [13]. Therefore, in most cases, targeted therapy is used in combination with chemotherapy; however, this strategy does not reduce the toxicity experienced with chemotherapeutic drugs.

To overcome the aforementioned constraints, chemotherapeutic agents from plants are becoming serious contenders as chemotherapeutic alternatives due to their manifestation of reduced toxicity to adjoining cells [14] while still providing potent anticancer effects in some cases. One such chemotherapeutic agent is curcumin (CUR), a major chemical constituent in turmeric, which has received much attention in the past decades because of its use in Indian and Chinese traditional medicine for centuries to treat a variety of conditions including infections, inflammation, and depression. It is also used as a spice. Thus, CUR is widely accepted by the public as it is derived from natural sources, all of which gives the perception that it is safe to use and likely to manifest fewer side effects when used therapeutically [15]. However, the systemic bioavailability following the oral administration of free CUR is poor due to the low solubility and rapid metabolism as stated earlier [16]. Aptly, extensive research has elaborated on the therapeutic potential of CUR against a range of cancers [17], but only through formulation intervention.

\section{Curcumin (CUR)}

\subsection{General Background Information}

CUR is a hydrophobic, orange-yellow, crystalline phytochemical derived from the rhizomes of turmeric (Curcuma longa), a plant which grows in the Indian subcontinent and tropical countries in South East Asia [13]. From ancient times, turmeric was therapeutically used to treat various respiratory conditions, liver disorders, abdominal pain, and many other ailments [18,19].

Later in the 13th century, turmeric was introduced to Europe as Indian saffron by Arab merchants and used as a colorant in foods, cosmetics, and textiles [20].

The primary source of turmeric is India, where about $80 \%$ of global turmeric is consumed [21]. Epidemiological studies attribute the low incidence of colon cancer in the Indian subcontinent to the chemo-preventive properties of diets rich in CUR [22].

The presence of a cluster of sesquiterpenes, such as (S)-ar-turmerone, zingiberene, $\beta$-turmerone, and curlone, and a variety of other volatile compounds (e.g., monoterpenes) in turmeric, gives its fragrance when used as a food seasoning [23]. The active constituents in turmeric are known as curcuminoids, with the major curcuminoid being a bis- $\alpha, \beta$-unsaturated diketone. Apart from CUR, also called diferuloylmethane, the other two bioactive analogs are demethoxycurcumin (DMC) and bisdemethoxycurcumin (BDMC). The chemical structures of the three curcuminoids are presented in Figure 1. 
<smiles>COc1cc(/C=C/C(=O)CC(=O)/C=C/c2ccc(O)c(OC)c2)ccc1O</smiles>

Curcumin<smiles>COc1cc(/C=C/C(=O)CC(=O)/C=C/c2ccc(O)cc2)ccc1O</smiles>

Demethoxycurcumin

Bisdemethoxycurcumin

Figure 1. Chemical structures of curcuminoids.

CUR is considered the principal curcuminoid that exhibits most of the therapeutic activities in turmeric [24]. Moreover, the characteristic yellow color of turmeric is attributable to CUR [25].

The bright yellow color of curcumin turns red and yellow in basic and acidic media, respectively [26]. It also fluoresces under ultraviolet light. In aprotic solvents (e.g., ethyl acetate and acetone), CUR has a noticeable fluorescent intensity variation from 494 to $538 \mathrm{~nm}$. In solvents such as alcohols and dimethyl sulfoxide (DMSO), the fluorescence shifts to $535-560 \mathrm{~nm}$, while the fluorescence spectrum of CUR in cyclohexane is notably distinct with two fluorescence maximas at 446 and $470 \mathrm{~nm}$ [27-29].

The IUPAC name of CUR is 1,7-bis (4-hydroxy-3-methoxy-phenyl) hepta-1, 6-diene-3, 5 -dione, with a molecular weight of $368.37 \mathrm{Da}$, melting point of $183^{\circ} \mathrm{C}$, and three $\mathrm{pKa}$ values of 7.80, 7.35, and 9.0 [14]. It demonstrates keto-enol tautomerism, with the predominant keto- form in acidic and neutral solutions, and a stable -enol form in alkaline media [30].

CUR is lipophilic and is thus insoluble in water, but soluble in organic solvents such as DMSO, methanol, acetone, and ethanol [22]. Furthermore, CUR is a potent H-atom donor at $\mathrm{pH}$ 3.0-7.0 and an electron donor at an alkaline $\mathrm{pH}$, at which it dissociates to form feruloyl methane, ferulic acid, and vanillin $[27,31,32]$. The bis-keto form of CUR dominates under acidic and neutral conditions, whereas the enol tautomer prevails at $\mathrm{pH}$ values over $8.0[14,20]$. The stability of CUR is considered pH-dependent, with the least stability in acidic media [32].

Shen and Ji [33] found that CUR degrades to dihydroferulic acid and ferulic acid in cell culture media with $10 \%$ fetal bovine serum and in in vivo studies. Even though the mechanism of degradation is still vague today, it is thought to be through its $\alpha, \beta$-unsaturated $\beta$-diketo moiety [34]. Fortunately, this constraint can be diminished by encapsulating CUR into either liposomes, cyclodextrin, lipids, surfactants, or polymeric nanoparticles (NPs) [29].

The most compelling and key rationale for the therapeutic use of CUR as an anticancer alternative is its extremely superior safety profile; thus, it is declared as GRAS (generally recognized as safe) by the United States Food and Drug Administration [18]. However, all the preclinical and clinical data from the oral administration of CUR have revealed that it manifests poor systemic bioavailability with high susceptibility to metabolic degradation, whereby only about $2.30 \mu \mathrm{g} / \mathrm{mL}$ of CUR was registered in serum levels after an oral administration of $10 \mathrm{~g}$ of CUR [20]. This shows that CUR undergoes extensive 
metabolic degradation prior to absorption within the intestine and liver, which minimizes its usefulness following oral intake.

\subsection{Pharmacological Properties of CUR}

In the last few decades, there has been an increased interest by researchers in the therapeutic effects of CUR as a natural alternative to chemical drugs in the management of several ailments [34]. Indeed, CUR is reported to possess a variety of pharmacological activities, including antimalarial [35-37], antibacterial [38,39], antiviral [40-42], antifungal [43,44], antioxidant [45-47], anti-inflammatory [45,48,49], antidiabetic [50,51], anti-human immunodeficiency virus [52-54], and anticancer [38,39,55-58] activities.

\subsection{Anticancer Properties of CUR}

Generally speaking, normal cells have a restrained balance between growth upholding and growth opposing signals [59]. Thus, the proliferation and differentiation of cells transpires only when required. However, this balance is disturbed in tumor cells, which show continuous cell proliferation, loss of differentiation, and programmed cell death. Consequently, a hyper-proliferative state of cells is attained, which presents as cancer [60]. Other peculiarities recognized in tumor cells include metastasis, angiogenesis, and apoptosis [61].

CUR has been extensively studied as a potential anticancer remedy, as well as a chemopreventive and direct therapeutic agent. The anticancer properties of CUR have been proven in vitro, in vivo, and in clinical studies. It is reported that the anticancer properties of CUR are exhibited via the inhibition of cell proliferation, induction of apoptosis, and devaluation of tumor load.

\subsubsection{Effects of CUR on Transcription Factors}

Specific transcription factors that are reported to be involved in the anticancer effect of CUR include nuclear factor kappa B (NF-KB) [62], activator protein-1 [63], early growth response-1 [64], peroxisome proliferator-activated receptor- $\gamma$ [65], signal transducer and activator of transcription, hypoxia inducible factor-1 [66], $\beta$-catenin [67], NF-E2-related factor 2 [68], electrophile response element [69], and androgen receptor [70]. CUR is believed to modulate various signaling pathways, thereby contributing to the activation of the aforementioned transcription factors [71]. Thus, CUR is able to regulate cell proliferation, inflammation, metastasis, angiogenesis, and invasion [66].

\subsubsection{Effects of CUR on Growth Factors and Protein Kinase}

CUR suppresses and downregulates the expression of several growth factors that contribute to the development of various cancers [72]. The activity of several tyrosine kinases increases due to mutations, which subsequently results in the malignant metamorphosis and metastasis of human cancers. CUR downregulates epidermal growth factor receptor (EGFR) activity and epidermal growth factor (EGF)-induced tyrosine phosphorylation of EGFR, eventually resulting in reduced protein kinase activity [73]. In addition, CUR suppresses the activities of protamine kinase, pp60c-src tyrosine kinase, autophosphorylation-activated protein kinase, and protein kinase C [74].

\subsubsection{Effects of CUR on Inflammatory Cytokines}

NF- $\mathrm{BB}$ is activated during the initial stages of inflammation. Consequently, the production of the multifunctional cytokine tumor necrosis factor (TNF) is upregulated, which, in turn, activates the production of interleukin (IL)-1 [75]. The activation of both TNF and IL-1 promotes the expression of several genes and proteins that engender acute and chronic inflammation [76]. It has been reported that chronic inflammation and activation of inflammatory cytokines mediate tumorigenesis $[75,77,78]$.

CUR shows a synergistic apoptotic effect when combined with TNF-related apoptosisinducing ligand. It also shows anti-inflammatory activity by blocking the phosphorylation of $\mathrm{I} \kappa \mathrm{B} \alpha$ and inhibitors of NF- $\mathrm{BB}$. This results in the inhibition of NF- $\kappa \mathrm{B}$ activation and, 
subsequently, TNF. Moreover, CUR inhibits TNF expression [79] as well as phorbol-methylacetate-induced TNF- $\alpha$ levels in various cells [80].

\subsubsection{Effects of CUR on Enzymes}

CUR has regulatory effects on various enzymes associated with inflammation and cancer, including fatty acid synthase, ATP-citrate lyase (ACLY), stearoyl-CoA desaturase 1, and cholesterol O-acyl-transferase [78,81]. Additionally, CUR potently inhibits carbonyl reductase $[82,83]$, downregulates the expression of other reductases in the aldo-keto reductase superfamily, and inhibits the transport of anthracyclines out of tumor cells [84].

Glutathione-S-transferase enzymes (GSTs) are reportedly involved in chemotherapy resistance in several cancer cell lines due to the methylation of GSTs [85]. CUR covalently binds to the catalytic thiolate of DNA methyltransferase 1, resulting in the blocking of DNA methylation of GSTs [86]. High levels of ACLY have been detected in various cancers such as breast, bladder, colorectal, lung, liver, prostate, and stomach tumors. ACLY activation is promoted by increased levels of glucose and insulin-like growth factors, which subsequently intervene in cancer progression [87]. However, CUR decreases the hepatic expression of ACLY [88].

Cyclooxygenase-2 (COX-2) expression is promoted by growth factors, inflammatory cytokines, oncogenes, carcinogens, and tumor promoters. However, COX-2 inhibitors are believed to aid in cancer prevention and treatment [85]. In a previous study, CUR was found to suppress COX-2 activity directly and selectively. Additionally, it inhibited bile acid and phorbol-ester-induced COX-2 expression and interferon-alpha-induced COX-2 activation [89]. These data clearly show that CUR has an anticancer effect.

\section{Potential of Nanodrug Delivery Systems in Cancer Treatment}

Nanodrug delivery has been proposed as the frontier for the effective delivery of anticancer agents and, hence, for cancer management. Oral nanodrug systems can be formulated to traverse the gastrointestinal epithelia effectively, and thus circumvent the metabolic constraints that the payload is subjected to within the gastrointestinal tract. According to the National Cancer Institute, nanotechnology has the potential of improving the current status of cancer detection, treatment, and prevention [90].

NPs have several characteristics ideal for the enhanced delivery of CUR in cancer management [91] (Figure 2). They exhibit a large surface area to volume ratio, high drug loading propensity, controlled drug release characteristics, and fairly good stability on storage [92]. NPs can be functionalized to deliver drugs specifically to cancer cells with minimal interaction with healthy tissue. Such targeting of NPs to cancer tissue is classified as either passive- or active-targeting [93]. The passive-targeting mechanism, also known as the EPR effect, occurs when NPs are in the size range of 10-100 nm, and, when in circulation, can selectively enter tumors through the surrounding leaky blood vessels and the interstitial space [94]. Owing to this EPR effect, NPs can also improve the safety and pharmacokinetic characteristics of active pharmaceutical ingredients [95]. Typically, NPs that employ the EPR effect to deliver drugs are intravenously administered since orally administered NPs have several hostile barriers to traverse within the gastrointestinal tract delivery in the systemic circulation. However, the active targeting of NPs to cancer cells entails specific ligand-receptor recognition and interaction on the cell surface [96]. 


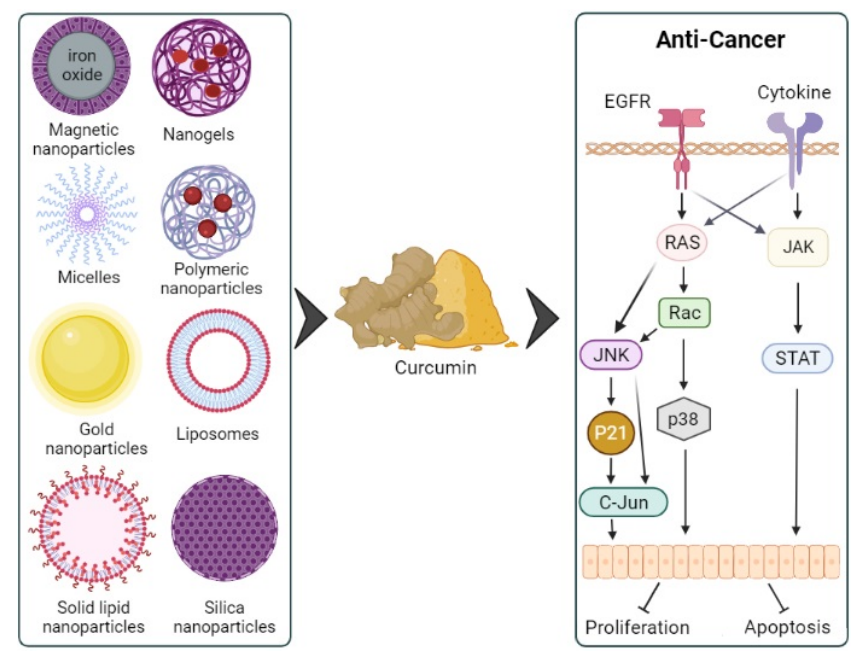

Figure 2. CUR-containing NP formulations with anticancer potential.

Typically, cancer cells express higher levels of cell-surface receptors as compared to normal cells. This allows NPs conjugated with a targeting ligand to explicitly interact with them via receptor-mediated molecular recognition. There are several examples of CUR-NP delivery systems, which may be subdivided into organic and inorganic NPs [97]. Their particle size, surface charge (zeta potential, ZP), hydrophilicity/hydrophobicity, and composition, among other characteristics, can be tailored for a diverse array of applications [98]. However, the primary consideration when designing any drug delivery system is to control drug concentration within the therapeutic window and improve patient compliance in order to maintain effective treatment cycles with short recovery periods.

The following sections are a review of potentially useful CUR-containing NP preparations for the management of different cancers.

\section{Prostate Cancer}

\subsection{Fibrinogen NPs}

CUR-loaded fibrinogen NPs (CUR-FNPs) (size: 150-200 nm; ZP: - $28 \mathrm{mV}$, encapsulation efficiency (EE): $90 \%$ ) fabricated through chemical cross-linking with $\mathrm{CaCl}_{2}$ in a two-step coacervation process were found to be comparatively non-toxic to normal fibroblast L929 cells, but toxic to PC-3 prostate cancer cells, whereas free CUR showed no cytotoxicity [99]. The CUR-FNPs also showed a dose-dependent apoptotic effect on the cancer cells with significant internalization and retention within the cells.

\subsection{Cyclodextrin (CD)-Based NPs}

Yallapu and colleagues [100] fabricated $\beta$-CD-CUR-NPs $(52.6 \mathrm{~nm})$ and found that uptake of the NPs by PC-3 cells was higher than that of free CUR. Similarly, the apoptosis rate was higher with the NPs, indicating the potential of the $\beta$-CD-CUR-NPs for managing prostate cancer. In addition, Ndong Ntoutoume and colleagues [101] prepared CUR$\mathrm{CD} /$ cellulose nanocrystal complexes $(206.8 \mathrm{~nm})$ by ionic interaction with improved CUR solubility. The NPs showed a higher antiproliferative effect against PC-3 and DU145 cancer cells compared to free CUR. The half-maximal inhibitory concentration $\left(\mathrm{IC}_{50}\right)$ values for the NPs after $48 \mathrm{~h}$ of treatment were 7.5 and $5.5 \mu \mathrm{M}$ against the PC-3 and DU145 cells, respectively, as opposed to 10 and $18 \mu \mathrm{M}$, respectively, for free CUR. These findings are promising; however, in vivo studies are needed to confirm the potential of these CD-based CUR-NPs for managing prostate cancer.

\subsection{Magnetic and Dendrimer-Based NPS}

In the study conducted by Yallapu and colleagues [100], CUR-loaded magnetic and dendrimer-based NPs (8.6 and $37.4 \mathrm{~nm}$, respectively) were also evaluated in PC-3 cells with 
similar cellular uptake findings. However, uptake was higher for the dendrimers due to their attachment to the cells. The considerably small sizes of these NPs hold potential for cancer management, but further studies are required.

\subsection{Polymeric NPS}

Yallapu and colleagues [100] also found that the uptake of CUR-NPs formulated with hydroxypropyl methyl cellulose (HPMC-CUR-NPs) and poly(lactic-co-glycolic acid) (PLGACUR-NPs) (5.2 and $58.1 \mathrm{~nm}$, respectively) was higher compared to free CUR in PC-3 cells. Unlike free CUR, the NPs also induced apoptosis, with superior effects from the HPMC-CURNPs. The HPMC-CUR-NPs had a greater antiproliferative effect and higher cytotoxicity via higher internalization, retention, and apoptosis compared to free CUR in C4-2, DU-145, PC-3, and LNCaP cells $\left(\mathrm{IC}_{50}: 11.5 \pm 4.2-37.4 \pm 3.2 \mu \mathrm{M}\right.$ vs. $\left.7.8 \pm 1.78-30.1 \pm 1.9 \mu \mathrm{M}\right)$. Clearly, the HPMC-CUR-NPs could be potentially useful in prostate cancer treatment.

In a later study, PLGA-CUR-NPs prepared via nanoprecipitation caused large and extensive vacuoles in C4-2 and DU-145 cells, but fewer and smaller vacuoles in PC-3 cells, which is possibly indicative of lesser NP uptake. Conversely, this was not observed in cells treated with free CUR. The NPs also inhibited cell growth better in vitro (especially at 4 and $6 \mu \mathrm{M}$ ) and reduced tumor volume in mice with C4-2 xenograft tumors better than the free drug without causing systemic toxicity. Additionally, the conjugation of prostate-specific membrane antigen (PSMA) monoclonal antibody to the NPs resulted in improved NP uptake and targeted CUR delivery to PSMA-expressing cells [102].

Rao and colleagues [103] have also prepared thermally-responsive CUR-NPs (EE, 54.3-73.9\%) using Pluronic F127 and chitosan via an emulsification-interfacial crosslinkingsolvent evaporation-dialysis method. NP size was reduced as temperature was increased from $22{ }^{\circ} \mathrm{C}(\sim 300 \mathrm{~nm})$ to $37^{\circ} \mathrm{C}(\sim 22 \mathrm{~nm})$. Mild hyperthermia $\left(43^{\circ} \mathrm{C}\right.$ for $\left.1-1.5 \mathrm{~h}\right)$ increased NP uptake, retention, and delivery to the nuclei of PC-3 cells. The $\mathrm{IC}_{50}$ of NPs plus hyperthermia was $>7$-fold lower than that of NPs only, suggesting that mild hyperthermia combined with the CUR-NPs may increase PC-3 cell destruction. However, no in vivo studies were conducted to support these results.

CUR-loaded, pH-sensitive, redox NPs (PR-CUR-NPs) (35 nm, 82\% EE) have been formulated using poly(ethylene glycol)-b-poly [4-(2,2,6,6-tetramethylpiperidine-1-oxyl) aminomethylstyrene]) by the dialysis method [104]. The PR-CUR-NPs improved CUR solubility, suppressed its oxidative degradation, and were significantly more toxic to PC-3 cells compared to free CUR or empty NPs. The PR-CUR-NPs (10 mg/kg, intravenously) also significantly reduced tumor volume in tumor-bearing nude mice compared to free CUR by suppressing oxidative stress.

Polyvinyl alcohol (PVA)-CUR-NPs $(46-67.3 \mathrm{~nm},-34.6 \pm 1.4$ to $-37 \pm 4.3 \mathrm{mV}$, 71.6-90.3\% EE) have been fabricated using the flash nanocomplexation technique via hydrogen bonding interactions [105] without an organic solvent. The cellular uptake and cytotoxicity of the NPs in PC-3 cells was negatively correlated to drug load. Interestingly, free CUR underwent a higher cellular uptake and was more cytotoxic than the NPs. Formulation optimization could possibly improve these findings.

\subsection{Lipid NPS}

In a recent study by Tanaudommongkon and colleagues [106], Miglyol 812 and dalpha-tocopheryl PEG succinate 1000 (MT) were used to formulate CUR-NPs (138.7 $\pm 5.4 \mathrm{~nm}$, $-24.4 \mathrm{mV}, 96.3 \pm 6.0 \% \mathrm{EE}$ ) by the nanoemulsion method. The NPs were cytotoxic to docetaxel (DTX)-resistant castration-resistant prostate cancer (CRPC) cells. Compared to free CUR, the CUR-MT-NPs were 5-fold and about 2-fold more cytotoxic to PC-3 and DU145 cells, respectively. The CUR-MT-NPs were also equally cytotoxic to sensitive and resistant cells, similar to the observation for free CUR against PC-3 cells. The CUR-MT-NPs completely overcame the resistance to DTX in both PC-3 and DU145 cells. 


\section{Lung Cancer}

\subsection{Liposomes}

Rahman and colleagues [107] fabricated liposomes (420 nm, EE > 66\%) containing $\beta C D-C U R$ complexes with better CUR water solubility than free CUR. The complexes and NPs were prepared by the methanol reflux and thin-film hydration methods, respectively. The median effective dose $\left(\mathrm{EC}_{50}\right)$ values for the CUR-loaded liposomes, free CUR, $\beta C D$ CUR, and $\beta C D-C$-loaded liposomes were 0.90, 1.5, 2.4, and $2.9 \mu \mathrm{M}$, respectively, on A549 cells $(p<0.05)$, clearly showing that increasing the aqueous solubility of CUR may not necessarily correlate with improved cytotoxicity.

\subsection{Lipid NPS}

Wang and colleagues [108] used the sol-gel method to fabricate CUR-loaded solid lipid nanoparticles (SLNs) (20-80 nm, -11.6 mV, 75\% EE) using stearic acid, lecithin, and polyoxyethylene (50) stearate. The $\mathrm{IC}_{50}$ of the CUR-SLNs $(4 \mu \mathrm{M})$ against A549 cells was 20-fold lower than that of free CUR. The NPs (200 mg/kg daily, 5 days/week, 19 days) had no effect on body weight, but significantly reduced tumor volume by $65.3 \%$ in nude female mice xenografted with A549 cells, compared to $19.5 \%$ by free CUR. Additionally, the SLNs significantly increased CUR bioavailability (26.4-fold) in female BALB/c mice and mostly accumulated in the lung and tumor tissues after intraperitoneal administration [108].

CUR-loaded cationic lipid NPs (CUR-CLNs) $(194.9 \pm 7.4 \mathrm{~nm},-28.15 \pm 2.25 \mathrm{mV}$, $\sim 98 \%$ EE) formulated by the emulsification evaporation-low temperature solidification method also showed better oral pharmacokinetic characteristics (higher bioavailability, higher plasma concentration, and lower clearance) compared to free CUR in rats. Following intravenous administration, the relative bioavailability of the CUR-CLNs to free CUR was $439.76 \%$. The CUR-CLNs also had a better anticancer effect in vitro (Lewis lung cancer, LLC cells; IC $5020.25 \mu \mathrm{M}$ vs. $39.70 \mu \mathrm{M}$ ) and in vivo (LLC-bearing C57BL/6J mice; tumor growth inhibition rate, $\sim 66$ vs. $\sim 39 \%$ ). The higher anticancer efficacy of the CUR-CLNs was attributed to the increased uptake and higher accumulation in the cells [109].

\subsection{Gold NPs}

Hoshikawa and colleagues [110] have developed PEGylated gold NPs with photothermal effects for CUR delivery. The NPs $(<10 \mathrm{mV})$ were conjugated to CD $(\alpha-, \beta-$, and $\gamma$-CDs) for CUR encapsulation, with $\beta-C D$ producing the highest CUR EE\%. The average size of the NPs, regardless of the CD used, was 25-35 nm (gold nanocore, $\sim 5 \mathrm{~nm}$ ). The CUR-CDAu-NPs were significantly cytotoxic to A549 cells; however, their effect was similar to that of free CUR.

\subsection{Polymeric NPS}

Yin and colleagues [111] have fabricated CUR-NPs using three amphiphilic methoxy PEG (mPEG)-polycaprolactone (PCL) block copolymers via the nanoprecipitation method, with the mPEG10k-PCL30k giving the highest drug loading efficiency and the most sustained drug release profile. The particle size, zeta potential (ZP), and encapsulation efficiency ranges were $102.3+11.3-140.3+14.2 \mathrm{~nm},-4.7+0.4$ to $-7.8+1.4 \mathrm{mV}$, and $75.2+6.3-83.1+5.8 \%$, respectively. Reduction of A549 cell viability after $24-72 \mathrm{~h}$ of treatment was better with the NPs compared to free CUR, but similar at doses $>80 \mu \mathrm{M}$. CUR uptake by the cells was also increased by the NPs [111].

CUR-coordinated ROS-responsive NPs (163.8 nm, $-0.31 \mathrm{mV}, 65 \% \mathrm{EE}$ ) have been fabricated using a biocompatible 4-(hydroxymethyl) phenylboronic acid-modified PEGgrafted poly(acrylic acid) polymer (PPH). The NPs improved CUR stability and were potent against A549 cancer cell proliferation in vitro. ROS inhibition with $N$-acetylcysteine resulted in the suppression of the cytotoxic effect of the NPs, which validates the selectivity of PPH-NPs for high-ROS cancer cells. Importantly, the findings showed that CUR release from the NPs was enhanced in the presence of ROS [112]. 
CUR-containing chitosan NPs $(170-200 \mathrm{~nm})$ have been prepared by ionic gelation and evaluated against human non-small cell lung carcinoma (H1299) cells [113]. Toxicity, bioavailability, and chemopreventive efficacy were evaluated in Swiss albino mice after the mice were administered the NPs or free CUR one week before treatment with benzo[a]pyrene (B[a]P), and then on alternative days for up to 4 months. CUR retention in the lungs of the mice was higher for the NPs than for free CUR. One fourth of the NP dose was also more potent in inhibiting B[a]P-induced lung carcinogenesis than free CUR was. Additionally, the CUR-loaded NPs were more effective in reducing nodule size, showing that the NPs can improve the chemopreventive efficacy of CUR against lung cancer.

\section{Colorectal Cancer (CRC)}

\subsection{Liposomes}

Pandelidou and colleagues [114] formulated and evaluated CUR-loaded liposomes $(108.0 \pm 8.9 \mathrm{~nm}, 85 \% \mathrm{EE})$ for anticancer effect against CRC cells. The liposomes were taken up by HCT116 cells to a greater extent than free CUR, and were subsequently more cytotoxic to HCT116, HCT15, and DLD-1 cells compared to free CUR $\left(\mathrm{IC}_{50}:<6 \mu \mathrm{M}\right.$ vs. 4.5-47.3 $\mu \mathrm{M})$. The liposomes improved CUR activity against the cells, showing a higher potency against the HCT116 and HCT15 cells.

In another study, Chen and colleagues [115] formulated $\mathrm{CaCO}_{3}$-encapsulated liposomes containing CUR (LCC) $(155.3 \pm 3.8 \mathrm{~nm},-14.2 \pm 0.3 \mathrm{mV}, 77.67 \pm 1.82 \% \mathrm{EE})$ with $\mathrm{pH}-$ sensitive properties for targeted CUR release by W/O emulsion-mediated film dispersion. The LCC formulation was more cytotoxic to HCT116 cells compared to free CUR or CURonly liposomes. Similarly, LCC caused a reduction in tumor volume in C57BL/6 mice with colon cancer better than CUR, attributable to enhanced CUR accumulation in the tumors.

In the aforementioned study by Rahman and colleagues [107], CUR-containing complexes and liposomes were also tested on SW-620 cancer cells, where the $\mathrm{EC}_{50}$ values for CUR-loaded liposomes, free CUR, CUR-loaded complexes, and $\beta C D-C$-loaded liposomes were $0.96,1.9,2.95$, and $3.25 \mu \mathrm{M}$, respectively. This finding was similar to the trend observed for the lung cancer cells, with the $\beta C D-C$ complex preparations having the lowest antiproliferative effects, possibly due to the higher aqueous solubility of CUR provided by the complex.

\subsection{Micelles}

Gou and colleagues [116] prepared CUR-containing monomethoxy PEG-PCL micelles $(27.3 \pm 1.3 \mathrm{~nm}, 99.16 \pm 1.02 \% \mathrm{EE})$ by the single-step nanoprecipitation method. Although the micelles were less cytotoxic to C-26 cells than free CUR $\left(\mathrm{IC}_{50}: 3.95 \mu \mathrm{g} / \mathrm{mL}\right.$ vs. $5.78 \mu \mathrm{g} / \mathrm{mL}$ ), the inhibition of angiogenesis was better in an alginate-encapsulated tumor cell assay. Importantly, the micelles ( $25 \mathrm{mg} / \mathrm{kg}$ CUR, intravenously) inhibited colon tumor growth in mice more than the free drug, showing their potential use in CRC management.

Another type of CUR-loaded micelles prepared with stearic acid-g-chitosan oligosaccharide (CSO-SA) $(114.7 \pm 16.9 \mathrm{~nm}, 18.5 \pm 0.4 \mathrm{mV}, 29.9 \pm 2.9 \% \mathrm{EE})$ was found to protect CUR from biotransformation and hydrolysis, thereby improving CUR stability. The CURCSO-SA micelles showed higher in vitro uptake and 6-fold higher cytotoxicity in CRC cells than free CUR. After 14 days of treatment, the CUR-CSO-SA micelles reduced tumor size and $\mathrm{CD} 44^{+} / \mathrm{CD} 24^{+}$cell subpopulation both in vitro and in nude mice [117].

Raveendran and colleagues [118] have used solvent dialysis to prepare a CUR-containing micelles using Pluronic/PCL amphiphilic block copolymer, with PCL, which is hydrophobic, forming the core of the micelles to improve CUR loading. The micelles $(195.7 \pm 7.3 \mathrm{~nm}$, $17.6 \pm 0.4 \mathrm{mV}, 72.08 \pm 4.29 \% \mathrm{EE}$ ) improved CUR uptake and cytotoxicity in Caco-2 cells.

In a later study, CUR-loaded micelles $(27.6 \pm 0.7 \mathrm{~nm}, 0.11 \pm 0.34 \mathrm{mV}, 96.08 \pm 3.23 \% \mathrm{EE})$ were also fabricated using monomethyl PEG-PCL and trimethylene carbonate (TMC) via a single-step solid dispersion method. TMC stabilized the micelles by inhibiting PCL crystallization. The micelles increased CUR uptake and cytotoxicity in CT26 cells, and 
were more effective in suppressing tumor growth in female BALB/c mice $(50 \mathrm{mg} / \mathrm{kg}$ CUR, intravenously) with fewer toxic effects [119].

Chang and colleagues [120] have also evaluated CUR micelles (34-80 nm, 58-63\% EE) prepared using poly(PEG methyl ether methacrylate)-block-poly(styrene) block copolymer in WiDr human colon carcinoma cells. Interestingly, larger micelles were more rapidly endocytosed and exocytosed than the smaller ones were. However, CUR-loaded micelles were better internalized by the cells than unloaded micelles. Additionally, after $72 \mathrm{~h}$ of exposure, smaller CUR-loaded micelles remarkably reduced cell proliferation compared to free CUR [120].

\subsection{Nanogel (NG)}

One benefit of NGs is that they confer structural stability to drug delivery systems and protect encapsulated drugs from degradation. Madhusudana Rao and colleagues [121] have used gelatin and acrylamidoglycolic acid to fabricate CUR-loaded $\mathrm{pH}$-sensitive NGs $(100 \mathrm{~nm}, 42-48 \% \mathrm{EE})$ by a simple emulsion polymerization technique. The stabilization of NG networks was achieved with glutaraldehyde. The in vitro CUR release was higher at $\mathrm{pH} 7.4$ than at 1.2. Compared to free CUR, the CUR-NGs showed better anticancer activity against HCT116 cells after $48 \mathrm{~h}$ of treatment.

Seok and colleagues [122] have also fabricated a hemocompatible NG using hyaluronic acid (HA) cross-linked zein for CUR delivery. The CUR-NG (200-250 nm, 20-40 mV, $94.15 \% \mathrm{EE}$ ) were more cytotoxic to CT26 cancer cells than normal NIH3T3 cells ( IC $_{50}$ : $37 \mu \mathrm{g} / \mathrm{mL}$ vs. $94 \mu \mathrm{g} / \mathrm{mL}$ ) via a higher apoptosis rate. The CUR-NG (3 mg/ $\mathrm{kg}$, intravenously) also showed a higher anticancer effect in BALB/c nude mice compared to free CUR [122].

Recently, Borah and colleagues [123] formulated CUR-loaded amylopectin-albumin core-shell NG functionalized with folic acid (FA) $(90 \mathrm{~nm},-24 \mathrm{mV}, 100 \% \mathrm{EE})$ that induced early-stage apoptosis of human HT29 cells, whereas free CUR did not. The NG also increased CUR uptake and retention (by 60\%) in FA receptor-positive HT29 cells. Additionally, it showed potential for oral delivery as it was resistant to degradation in simulated gastric and intestinal fluids.

\subsection{CD-Based NPs}

Ndong Ntoutoume and colleagues [101] have formulated CUR-loaded CD/cellulose nanocrystal complexes by ionic interaction $(206.8 \mathrm{~nm},-29.6 \pm 2.7 \mathrm{mV})$ that improved CUR uptake by HT29 cells and exhibited an anticancer effect that was 3-4 times more effective than CUR alone. These NPs also increased the aqueous solubility of CUR.

In another study, CUR-NPs (169-338 nm, $17.1 \mathrm{mV}, 53.0 \% \mathrm{EE})$ fabricated using chitosan, HA, and sulfobutyl-ether- $\beta-C D$ by ionic gelation also significantly inhibited HT29 cell proliferation. The NPs were better internalized by the cancer cells compared to normal I407 cells. The aqueous solubility of CUR was also improved $(3.72 \mu \mathrm{g} / \mathrm{mL}$ to $70 \mu \mathrm{g} / \mathrm{mL})$ after encapsulation into NPs [124].

\subsection{Lipid NPs}

Chirio and colleagues [125] have fabricated CUR-SLNs $(<300 \mathrm{~nm}, 22.13 \pm 3.19 \mathrm{mV}$, $28-81 \%$ EE) by coacervation based on fatty acid precipitation. The highest EEs were obtained with palmitic acid or PVA 9000. Interestingly, the different SLNs prepared, whether loaded with CUR or not, had similar cytotoxic effects against HCT116 cells, which is attributable to low CUR EE and reduced CUR solubility in NPs with higher EEs.

\subsection{Gold NPs}

Positively charged CUR-Au-NPs $(160 \pm 20 \mathrm{~nm}, 18 \pm 3 \mathrm{mV})$ with pH-, radiofrequencyand thermo-responsive properties have been formulated by Sanoj Rejinold and colleagues [126]. The NPs remained in tumors in mice bearing CT26 xenografts for up to 2 weeks. Additionally, the circulation time of CUR in the blood was much longer (up to a week) for the NPs 
compared to free CUR. Importantly, CUR accumulation was higher in tumors than in other organs, showing the potential of the NPs in targeted treatment of colon cancer.

Alibolandi and colleagues [127] have also formulated CUR-loaded hybrid dendrimer Au-NPs (<10 nm). PEG-Au-poly(amidoamine) (PAMAM) NPs were prepared first and then loaded with CUR. Mucin-1 conjugated aptamer (Apt) increased the uptake and cytotoxicity of the NPs in HT29 and C26 cells. The in vivo antitumor effects (survival rate and tumor growth inhibition) of the NPs ( $2 \mathrm{mg} / \mathrm{kg}$ CUR, intravenously, BALB/c mice) were better than those of free CUR, and were further improved with the Apt-conjugated NPs.

\subsection{Polymeric NPS}

Chuah and colleagues [128] have formulated CUR-loaded chitosan NPs (340 $\pm 4.5 \mathrm{~nm}$, $43.7 \pm 0.4 \mathrm{mV}, 77.44 \pm 0.2 \% \mathrm{EE}$ ) to enhance colonic CUR delivery through mucoadhesion. The CUR-NPs had better mucoadhesion properties than the empty NPs. Uptake of the CUR-NPs by HT29 cells was also higher than that of free CUR. Additionally, HT29 cell viability was better reduced after $72 \mathrm{~h}$ of treatment and when CUR was loaded into the NPs.

CUR-NPs have been fabricated with PLGA, soybean lecithin, and DSPE-PEG $2000^{-}$ $\mathrm{COOH}$ via nanoprecipitation, and functionalized with a ribonucleic acid Apt against epithelial cell adhesion molecule, which is overexpressed on colorectal adenocarcinoma cells, for targeted CUR delivery. The Apt-CUR-NPs $(90 \pm 1.9 \mathrm{~nm},-36.3 \pm 4.2 \mathrm{mV}, 89.98 \pm 3.8 \% \mathrm{EE})$ showed 64-fold higher binding and/or internalization by HT29 cells than CUR-NPs functionalized with negative control Apt. The Apt-CUR-NPs also had a higher antiproliferative activity against HT29 colon cells than free CUR and a significantly higher bioavailability and 6-fold longer half-life in male Sprague Dawley rats than the free drug, showing their potential benefit in CRC treatment [129].

CUR-loaded polymeric NPs (136 nm, $48 \mathrm{mV}, 95 \% \mathrm{EE})$ have also been fabricated using chitosan and gum arabic by Udompornmongkol and Chiang [130] via emulsificationsolvent diffusion. The NPs were stable in simulated gastrointestinal fluids. Their uptake by HCT116 and HT29 cells, as well as their antiproliferative effect against the cells, were better than those of free CUR, showing the anti-CRC potential of the NPs.

In another study, CUR-NPs prepared by emulsification-diffusion-evaporation using Eudragit E $100(248.40 \pm 3.89 \mathrm{~nm}, 65.77 \pm 3.17 \% \mathrm{EE})$ had a 19-fold higher inhibition rate on the growth of Colon-26 cells, had a better oral bioavailability in Wistar rats, and a reduced tumor volume in Colon-26 tumor-bearing BALB/c mice $(50 \mathrm{mg} / \mathrm{kg}$ CUR, orally, daily for 30 days) as compared to free CUR, showing the potential of the CUR-NPs in CRC management [131].

Silk fibroin (SF) has been used to fabricate CUR-NPs $(<100 \mathrm{~nm})$ via solution-enhanced dispersion by the supercritical $\mathrm{CO}_{2}$ technique. The $\mathrm{IC}_{50} \mathrm{~S}$ of free CUR, CUR-SF-NPs, and fluorouracil against HCT116 cells were $5.339,4.383$, and $0.432 \mu \mathrm{g} / \mathrm{mL}$, respectively; however, the CUR-SF-NPs had the most superior anticancer effect at CUR concentrations $>10 \mu \mathrm{g} / \mathrm{mL}$ [132].

Polymeric self-emulsifying NPs (100-180 nm, $64.85 \pm 0.12 \%$ EE) were formulated by Wadhwa and colleagues [133] via quasi-emulsion solvent diffusion using HPMC acetate succinate. The in vitro release studies showed that up to a $5 \mathrm{~h}$ lag time preceded CUR release from the NPs, which approximates the time for cecal arrival following oral intake. Furthermore, the optimized NPs were more cytotoxic to HT29 cells than free CUR (IC 50 : $20.32 \mu \mathrm{M}$ vs. $28.56 \mu \mathrm{M}$ ), and CUR was successfully delivered to the colon in guinea pigs by the NPs, even though they were not well absorbed in this region.

Alkhader and colleagues [134] have prepared CUR-containing chitosan-pectinate NPs (CUR-CS-PEC-NPs) $(206.0 \pm 6.6 \mathrm{~nm}, 32.8 \pm 0.5 \mathrm{mV}, 64 \% \mathrm{EE})$ that are more mucoadhesive at an alkaline $\mathrm{pH}$ than at an acidic $\mathrm{pH}$. A very high CUR release $(>80 \%)$ was achieved in a pectinase-enriched medium ( $\mathrm{pH}$ 6.4), indicating that the NPs are suited for colon-targeted CUR delivery. In a further study, Alkhader and colleagues [135] found that free CUR and CUR-CS-PEC-NPs inhibited HT29 cell proliferation in a dose- and time-dependent manner. Uptake of free CUR and CUR-CS-PEC-NPs by HT29 cells was comparable; however, the oral bioavailability of CUR in Sprague Dawley rats was significantly higher for the NPs. 
Sabra and colleagues [136] have also formulated CUR-loaded modified citrus pectinchitosan NPs (MCPC-CUR-NPs; $178 \pm 0.896 \mathrm{~nm}, 35.7 \pm 1.41 \mathrm{mV}, 69.43 \% \mathrm{EE}$ ) that exhibit mucoadhesive properties using a one-step ionic gelation technique. Similar to the findings of Alkhader and colleagues [134], the MCPC-CUR-NPs exhibited a better mucoadhesive property at $\mathrm{pHs}$ of 7.0, 5.5, and 6.25 than at 1.2. Additionally, CUR release over $24 \mathrm{~h}$ from the NPs was higher in a $33 \%(w / v)$ cecal medium than in an acidic medium $(\mathrm{pH} 1.2)$ (68\% versus $18 \%$ ). In a further study, the MCPC-CUR-NPs showed more toxicity to HT29 and HCT-116 cells compared to unmodified NPs or free CUR, particularly after $\geq 48 \mathrm{~h}$ of treatment. Additionally, pectin modification significantly increased the cellular uptake of the NPs, especially at low CUR concentrations [137]. These results show that MCPC-CURNPs may be beneficial in the management of CRC.

\section{Breast Cancer}

\subsection{Lipid NPS}

CUR-loaded transferrin-mediated SLNs (Tf-CUR-SLNs; $206 \pm 3.2 \mathrm{~nm}, 8.21 \pm 0.89 \mathrm{mV}$, $77.27 \pm 2.34 \%$ EE) prepared by homogenization have been shown to increase CUR photostability and inhibit MCF-7 cell proliferation. Cellular uptake of the Tf-CUR-SLNs was higher than that for free CUR or CUR-SLNs, possibly due to the targeting effect by Tf-CUR-SLNs on MCF-7 cells [138].

Sun and colleagues [139] fabricated CUR-loaded SLNs (152.8 $\pm 4.7 \mathrm{~nm}, 90 \%$ EE) by high-pressure homogenization, where cell viability was inhibited for a prolonged period, whereas cells treated with free CUR recovered viability after $72 \mathrm{~h}$, confirming the superiority of the NPs. The cellular uptake of the NPs increased from $10 \mathrm{~min}$ to $3 \mathrm{~h}$ of incubation, then decreased after 3-6 h. On the other hand, uptake of free CUR was rapid in the first $10 \mathrm{~min}$, but decreased sharply afterwards. Additionally, the bioavailability of CUR in Sprague Dawley rats after intravenous administration was 1.25-fold higher from the NPs compared to free CUR.

Wang and colleagues [140] have also prepared CUR-SLNs by low-temperature solid emulsification using stearic acid and lecithin as lipids. The CUR-SLNs $(40 \mathrm{~nm},-25.3 \pm 1.3 \mathrm{mV}$, $72.47 \%$ EE) induced a higher level of cytotoxicity and apoptosis (IC $50: 28.42 \mu \mathrm{M}$ vs. $18.78 \mu \mathrm{M}$ ) and were better taken up by SK-BR-3 breast cancer cells than free CUR. Similar to several of the reported studies on CUR-loaded NPs, no in vivo anticancer evaluations were performed.

Minafra and colleagues [141] produced CUR-SLNs (302.5 nm, $41.4 \pm 4.6 \mathrm{mV}, 68.62 \%$ EE) with radiosensitizing ability by ethanolic precipitation followed by homogenization. Free CUR and the CUR-SLNs had a comparable cytotoxic effect on MDA-MB-231 breast cancer cells. Irradiation of cancer cells that had accumulated by CUR-SLNs with 2 Gy of photon beam resulted in the protection against radiation-induced oxidative stress and an antitumor effect through the activation of autophagy simultaneously. These findings necessitate further studies on the concomitant use of CUR-SLNs and radiotherapy for treating breast cancer.

\subsection{NG}

Wei and colleagues [142] have prepared a NG loaded with CUR conjugated to cholesterylHA (CHA) for targeted CUR delivery to CD44-expressing drug-resistant cancer cells. The NG particles $(20 \mathrm{~nm})$ were stable in simulated gastrointestinal fluids and had a 400 -fold higher aqueous solubility than pure CUR. The NG was also more cytotoxic to 4T1 cells $\left(\mathrm{IC}_{50}: 2 \mu \mathrm{g} / \mathrm{mL}\right.$ vs. $5 \mu \mathrm{g} / \mathrm{mL}$ ) and inhibited tumor growth in BALB/c mice better than free CUR did.

\subsection{Silica NPS}

Li and colleagues [143] found that CUR-loaded mesoporous silica NPs (MSNs) modified with HA or polyethyleneimine (PEI)-FA were more cytotoxic to MDA-MB-231 cells at 20-60 $\mu \mathrm{g} / \mathrm{mL}$ than free CUR, CUR-MSNs, or CUR-PEI-MSNs were. This was attributed to the affinity of the CUR-PEI-FA-MSNs for FA and CD44 receptors, which are typically overexpressed on MDA-MB-231 cells. Cellular uptake was in the order: CUR-PEI-FA- 
MSNs $>$ CUR-HA-MSNs $>$ CUR-PEI-MSNs $>$ CUR-MSNs $>$ free CUR. The CUR-PEI-FAMSNs ( $8 \mathrm{mg} / \mathrm{kg}$ CUR, every 3 days via the tail vein) showed the best antitumor effect in female BALB/c nude, pointing to the importance of suitably surface-modified NPs in cancer management.

\section{4. $\mathrm{ZnONPs}$}

CUR-loaded phenyl boronic acid (PBA)-conjugated and pH-responsive ZnO NPs (CUR-ZnO-PBA-NPs) $(413.63 \pm 9.5 \mathrm{~nm},-16.4 \pm 0.30 \mathrm{mV}, 27 \%$ EE) have been fabricated by Kundu and colleagues [144]. The uptake of ZnO-PBA-NPs was higher than ZnO-NPs by MCF-7 cells. Furthermore, CUR-ZnO-PBA-NPs were more cytotoxic to MCF-7 cells, accumulated more in tumors, and reduced tumor volume better in Swiss albino mice (10 mg/kg CUR, intravenously on alternate days for 14 days) compared to free CUR. Intriguingly, the CUR-ZnO-PBA-NPs alleviated tumor-induced splenomegaly, which could be valuable in breast cancer patients.

\subsection{Hybrid Magnetic-Polymeric NPs}

CUR-loaded magnetic alginate/chitosan NPs (CUR-MAC-NPs) (172-199 nm, -28.7 to $-34.2 \mathrm{mV}, 67.5 \% \mathrm{EE})$ prepared via co-precipitation were internalized by MDA-MB-231 3-6 fold higher than free CUR. The CUR-MAC-NPs were also significantly less toxic to normal human dermal fibroblasts. However, in vivo studies are needed to clarify the potential of the CUR-MAC-NPs using an external magnetic field [145].

\subsection{Human Serum Albumin (HSA) NPS}

Saleh and colleagues [146] have formulated CUR-containing HSA-NPs decorated with human epidermal growth factor receptor 2 (HER2) Apt (Apt-CUR-HSA-NPs; $281.1 \pm 11.1 \mathrm{~nm}$, $-33.3 \pm 2.5 \mathrm{mV}, 71.3 \% \mathrm{EE} \%$ ) through desolvation. The NPs increased the aqueous solubility of CUR 400-fold. Additionally, the presence of Apt increased the cytoplasmic uptake and cytotoxicity of the NPs in HER2-overexpressing SK-BR-3 cells, indicating that the Apt-CURHSA-NPs may be a promising treatment for HER2-positive breast cancer. Recently, Hasanpoor and colleagues (2020) similarly fabricated CUR-HSA-NPs and functionalized the particles with programmed death ligand 1 (PDL1) binding peptide, with the peptide-CUR-HSA-NPs $(246.5 \mathrm{~nm},-24.5 \pm 1.5 \mathrm{mV}, 77.8 \% \mathrm{EE})$ showing a similar trend of uptake and cytotoxicity in high PDL1-expressing MDA-MB-231 cells. Matloubi and Hassan [147] have likewise fabricated CUR-HSA-NPs ( $220 \mathrm{~nm},-7 \mathrm{mV}, 70 \% \mathrm{EE})$, but without surface functionalization. The cytotoxicity of the NPs was lesser on peripheral blood mononuclear cells, but higher on MCF7 and SK-BR3 cells from $48 \mathrm{~h}$ of treatment compared to free CUR. These findings are promising, with regard to improved anticancer effects due to NP surface functionalization. However, further studies in animal models are needed to show their potential in breast cancer management.

\subsection{Magnetic NPs}

Ashkbar and colleagues [148] found that $\mathrm{Fe}_{3} \mathrm{O}_{4}-\mathrm{SiO}_{2}$-CUR-NPs $(20-60 \mathrm{~nm},-57.5 \mathrm{mV})$ combined with photodynamic therapy (PDT) and photothermal therapy (PTT) produced the highest reduction of $4 \mathrm{~T} 1$ tumor volume in female BALB/c mice compared to the NPs only, free CUR plus PDT, NPs plus PTT, or PDT plus PTT. Importantly, tumor volume was decreased by $58 \%$ by the NPs alone compared to the untreated group. These show the benefit of the CUR-NPs and, even more significantly, the potential of the triple therapy in breast cancer management.

\subsection{Polymeric NPs}

Khan and colleagues [149] fabricated CUR-PLGA NPs (265-606 nm, -3.1 to $-13.7 \mathrm{mV}$, $>50 \%$ EE) by solvent evaporation and tested them on MDA-MB-231 cells, whereby a 10-fold increase in solubility and 3-fold increase in anticancer activity compared to CUR was observed. Sampath and colleagues [150] have investigated the use of tocopherol PEG 1000 
succinate (TPGS, as emulsifier) with different capping agents (chitosan, dextran, and PEG) to fabricate CUR-PLGA-NPs by emulsion solvent evaporation $(<200 \mathrm{~nm}, 7.94-40.47 \mathrm{mV}$, 82-89\% EE). All NPs produced reduced MCF-7 cell proliferation better than free CUR did, with the highest cellular uptake observed when TPGS and dextran were used.

CUR-loaded poly-glycerol-malic acid-dodecanedioic acid NPs (110-218 nm, -17.5 to $-18.9 \mathrm{mV}, 75-81 \% \mathrm{EE})$ fabricated via nanoprecipitation have shown a higher antiproliferative effect against MCF-7 and MDA-MB 231 cells compared to free CUR. Interestingly, the cytotoxicity of free CUR decreased with increasing incubation periods, whereas the reverse was observed for the NPs after 7 days [151].

\subsection{Phospholipid-Polymeric NPS}

CUR-loaded phospholipid NPs conjugated with EGF have been formulated via thinfilm hydration by Jung and colleagues [152]. The EGF-CUR-NPs (229.3 $\pm 6.0 \mathrm{~nm}, 63.3 \% \mathrm{EE})$ exhibited a dose-dependent suppression of MDA-MB-468 TNBC cell survival and were more cytotoxic than free CUR or CUR-only NPs. The EGF-CUR-NPs $(10 \mathrm{mg} / \mathrm{kg}$, intraperitoneally, three times weekly, total of 8 injections) also suppressed tumor growth in mice bearing MDA-MB-468 tumors better compared to empty or CUR-only NPs, showing that they may be beneficial for treating TNBCs with an overexpression of EGF receptors.

\subsection{Polymer-Coated Gold NPS}

FA-functionalized CUR-Au-PVP-NPs (358.7 nm, -12.5 mV) prepared by layer-bylayer assembly have been shown to be cytotoxic to MDA-MB-231, MCF-7, and 4T1 cancer cells, but not to normal L929 and MCF-10A cells at CUR concentrations of $<100 \mu \mathrm{g} / \mathrm{mL}$. The FA-CUR-Au-PVP NPs (10 mg/kg, intratumorally, 2 weeks) inhibited tumor growth in $\mathrm{BALB} / \mathrm{c}$ mice bearing $4 \mathrm{~T} 1$ tumors more than free CUR [153].

\subsection{Radiolabeled NPS}

Huang and colleagues [154] used membrane dialysis to fabricate self-assembled 99mTcradiolabeled CUR-NPs with HA-cholesteryl hemisuccinate conjugates and D-a-TPGS. The NPs (144 nm, $-21.25 \pm 1.66 \mathrm{mV}, 84.0 \pm 5.0 \% \mathrm{EE})$ inhibited $4 \mathrm{~T} 1$ cell growth by twofold compared CUR ( $\mathrm{IC}_{50}$ values: $38 \mu \mathrm{g} / \mathrm{mL}$ vs. $77 \mu \mathrm{g} / \mathrm{mL}$ ). Tumor growth in tumorbearing BALB/c mice was also inhibited by the NPs $(50 \mathrm{mg} / \mathrm{kg}$, every 2 days, total of 5 injections) without toxicities to major organs; however, the in vivo effect of free CUR was not determined.

\subsection{NG}

Setayesh and colleagues [155] grafted octadecylamine (ODA) to chondroitin sulfate (CS) to form a CS-ODA conjugate that was used to prepare CUR-loaded NG (311 $\pm 20.29 \mathrm{~nm}$, $-13.25 \pm 0.35 \mathrm{mV}, 79.56 \pm 5.56 \% \mathrm{EE})$. Interestingly, the CS-ODA-NG and free CUR were equally cytotoxic to MCF-7 cells after $\geq 48 \mathrm{~h}$ of incubation; however, cellular uptake of the NG was higher.

\section{Oral, Cervical, Ovarian, and Pancreatic Cancers}

Reported studies on the evaluation of CUR nanoformulations for oral, cervical, ovarian, and pancreatic cancers have been summarized in Table 1. 
Table 1. Summary of details from studies on CUR nanoformulations for ovarian, oral, cervical, and pancreatic cancers.

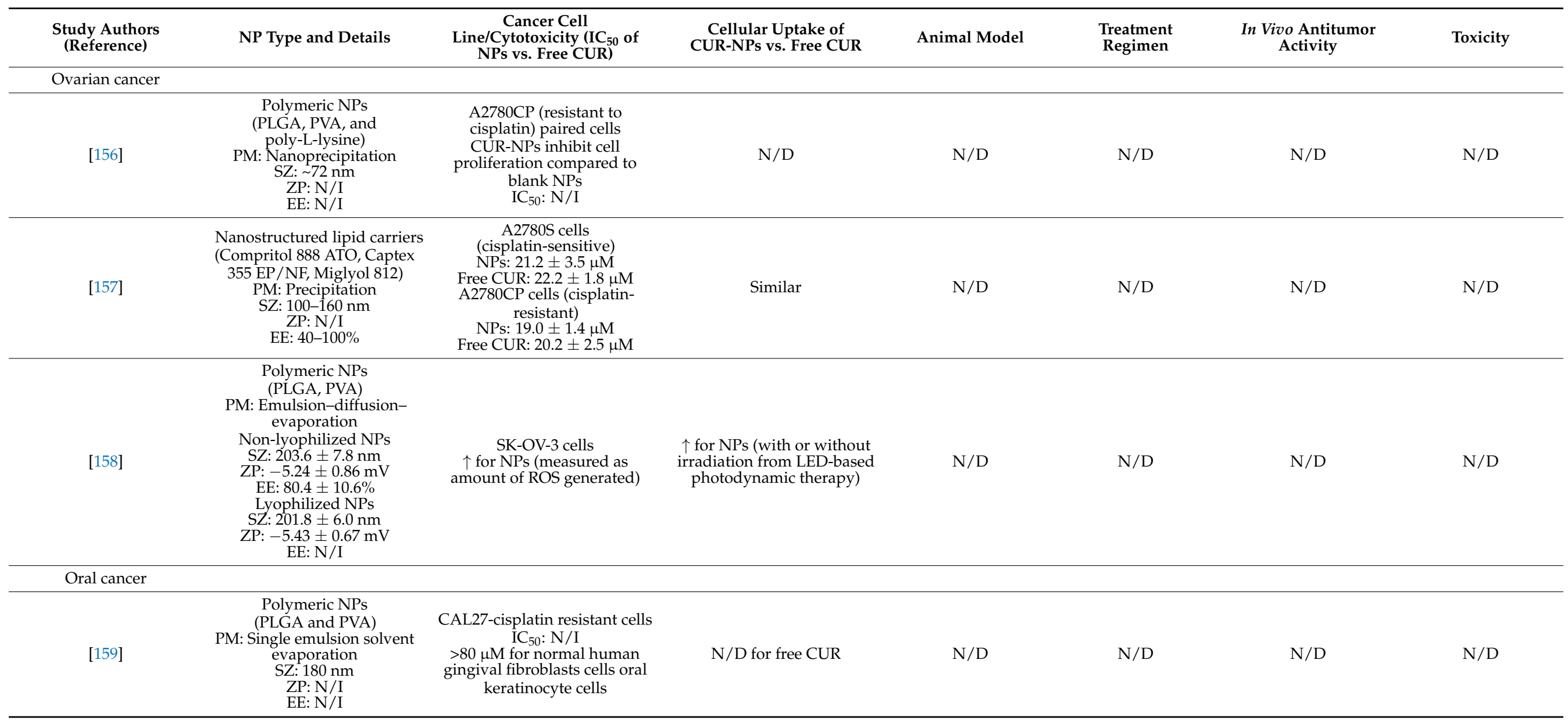


Table 1. Cont.

\begin{tabular}{|c|c|c|c|c|c|c|c|}
\hline $\begin{array}{l}\text { Study Authors } \\
\text { (Reference) }\end{array}$ & NP Type and Details & $\begin{array}{c}\text { Cancer Cell } \\
\text { Line/Cytotoxicity (IC } 50 \text { of } \\
\text { NPs vs. Free CUR) }\end{array}$ & $\begin{array}{l}\text { Cellular Uptake of } \\
\text { CUR-NPs vs. Free CUR }\end{array}$ & Animal Model & $\begin{array}{l}\text { Treatment } \\
\text { Regimen }\end{array}$ & $\begin{array}{l}\text { In Vivo Antitumor } \\
\text { Activity }\end{array}$ & Toxicity \\
\hline [160] & $\begin{array}{c}\text { Silica NPs } \\
\text { (Vinyltriethoxysilane, } \\
\text { 3-aminopropyl- } \\
\text { trimethoxysilane) } \\
\text { PM: N/I } \\
\text { SZ: } \sim 32 \mathrm{~nm} \\
\text { ZP: }-39 \pm 1.0 \mathrm{mV} \\
\text { EE: N/I }\end{array}$ & $\begin{array}{l}\text { Human squamous cell } \\
\text { carcinoma }(4451) \text { cells } \\
\text { IC } 50: \mathrm{N} / \mathrm{I}\end{array}$ & $\uparrow$ for NPs & $\mathrm{N} / \mathrm{D}$ & $\mathrm{N} / \mathrm{D}$ & $\mathrm{N} / \mathrm{D}$ & $\mathrm{N} / \mathrm{D}$ \\
\hline [161] & $\begin{array}{l}\text { Chitosan-coated } \\
\text { PCL NPs } \\
\text { PM: Nanoprecipitation } \\
\text { SZ: 115.3-127.3 nm } \\
\text { ZP: } 23.5-40.1 \mathrm{mV} \\
\text { EE: }>99 \%\end{array}$ & $\begin{array}{c}\text { SCC-9 cells } \\
24 \mathrm{~h} \\
\text { NPs: } 271.5 \pm 1.17 \mu \mathrm{M} \\
\text { Free CUR: } 93.40 \pm 4.26 \mu \mathrm{M} \\
48 \mathrm{~h} \\
\text { NPs: } 260.3 \pm 8.35 \mu \mathrm{M} \\
\text { Free CUR: } 75.21 \pm 3.25 \mu \mathrm{M} \\
72 \mathrm{~h} \\
\text { NPs: } 92.04 \pm 1.53 \mu \mathrm{M} \\
\text { Free CUR: } 17.46 \pm 1.20 \mu \mathrm{M} \\
\text { ( } p<0.05 \text { in each instance) } \\
\text { Free CUR was more cytotoxic } \\
\text { than the NPs }\end{array}$ & $\mathrm{N} / \mathrm{D}$ & $\mathrm{N} / \mathrm{D}$ & $\mathrm{N} / \mathrm{D}$ & $\mathrm{N} / \mathrm{D}$ & $\mathrm{N} / \mathrm{D}$ \\
\hline \multicolumn{8}{|l|}{ Cervical cancer } \\
\hline [162] & $\begin{array}{l}\text { NG (FA-conjugated } \\
\text { cross-linked polymeric NPs) } \\
\text { (acrylic acid, PEG diacrylate, FA) } \\
\text { PM: Inverse emulsion } \\
\text { polymerization } \\
\text { SZ: } 160-190 \mathrm{~nm} \\
\text { ZP: N/I } \\
\text { EE: } 61.2 \pm 1.2 \%\end{array}$ & $\begin{array}{l}\text { HeLa cells } \\
\uparrow \text { for NPs } \\
\mathrm{IC}_{50}: \mathrm{N} / \mathrm{I}\end{array}$ & $\uparrow$ for NPs & ND & ND & ND & ND \\
\hline
\end{tabular}


Table 1. Cont.

\begin{tabular}{|c|c|c|c|c|c|c|c|}
\hline $\begin{array}{l}\text { Study Authors } \\
\text { (Reference) }\end{array}$ & NP Type and Details & $\begin{array}{c}\text { Cancer Cell } \\
\text { Line/Cytotoxicity (IC } 50 \text { of } \\
\text { NPs vs. Free CUR) }\end{array}$ & $\begin{array}{l}\text { Cellular Uptake of } \\
\text { CUR-NPs vs. Free CUR }\end{array}$ & Animal Model & $\begin{array}{l}\text { Treatment } \\
\text { Regimen }\end{array}$ & $\begin{array}{c}\text { In Vivo Antitumor } \\
\text { Activity }\end{array}$ & Toxicity \\
\hline [163] & $\begin{array}{c}\text { Liposomes } \\
\text { (soybean lecithin and } \\
\text { cholesterol, Montanov82 } \\
\text { and/or DDAB) } \\
\text { PM: Thin film } \\
\text { hydration method } \\
\text { CUR-NPs (with } \\
\text { Montanov82 } \\
\text { SZ: } 161.5 \pm 0.8 \mathrm{~nm} \\
\text { ZP: }-1.4 \pm 0.8 \mathrm{mV} \\
\text { EE: } 63.9 \pm 3.8 \% \\
\text { CUR-NPs (with cholesterol) } \\
\text { SZ: } 161.8 \pm 0.4 \mathrm{~nm} \\
\text { ZP: }-0.1 \pm 0.1 \mathrm{mV} \\
\text { EE: } 70.6 \pm 0.5 \% \\
\text { CUR-NPs (with } \\
\text { Montanov82 }{ }^{\circledR} \text { and DDAB) } \\
\text { SZ: }: 52.4 \pm 5.3 \mathrm{~nm} \\
\text { ZP: } 28.8 \pm 1.0 \mathrm{mV} \\
\text { EE: } 34.7 \pm 0.3 \% \\
\text { CUR-NPs (with cholesterol } \\
\text { and DDAB) } \\
\text { SZ: } 219.5 \pm 9.3 \mathrm{~nm} \\
\text { ZP: } 27.7 \pm 0.9 \mathrm{mV} \\
\text { EE: } 68.9 \pm 0.6 \%\end{array}$ & $\begin{array}{c}\text { HeLa cells } \\
\uparrow \text { for NPs than free CUR } \\
\text { NPs: N/I } \\
\text { Free CUR: } 21 \mu \mathrm{M} \\
\text { SiHa cells } \\
\uparrow \text { for NPs than free CUR } \\
\text { NPs: N/I } \\
\text { Free CUR: } 16 \mu \mathrm{M} \\
\text { For both cells, cytotoxicity } \uparrow \\
\text { for NPs containing DDAB }\end{array}$ & $\mathrm{N} / \mathrm{I}$ & ND & ND & ND & ND \\
\hline [164] & $\begin{array}{c}\text { Micelles } \\
\text { (N-benzyl- } N, O \text {-succinyl } \\
\text { chitosan synthesized from } \\
\text { chitosan by } \\
\text { successive reductive } \\
N \text {-benzylation, and } \\
N, O \text {-succinylation) } \\
\text { PM: Dialysis method } \\
\text { SZ: } 80 \pm 4.0-97 \pm 5.0 \mathrm{~nm} \\
\mathrm{ZP}:-27.1 \pm 1.4 \text { to } \\
-29.2 \pm 1.4 \mathrm{mV} \\
\text { EE: } 7.57 \pm 0.01-38.30 \pm \\
5.70 \%\end{array}$ & $\begin{array}{c}\text { HeLa cells } \\
\text { NPs: } 4.34 \pm 0.12 \mu \mathrm{M}(4.7 \text {-fold } \\
\downarrow) \\
\text { Free CUR: } 21.17 \pm 1.80 \mu \mathrm{M} \\
\text { SiHa cells } \\
\text { NPs: } 4.34 \pm 0.12 \mu \mathrm{M}(3.6 \text {-fold } \\
\downarrow) \\
\text { Free CUR: } 16.28 \pm 1.34 \mu \mathrm{M} \\
\text { C33A cells } \\
\text { NPs: } 4.34 \pm 0.12 \mu \mathrm{M}(12.2 \text {-fold } \\
\downarrow) \\
\text { Free CUR: } 54.29 \pm 3.62 \mu \mathrm{M}\end{array}$ & Significantly $\uparrow$ for all NPs & - & - & - & - \\
\hline
\end{tabular}


Table 1. Cont.

\begin{tabular}{|c|c|c|c|c|c|c|c|}
\hline $\begin{array}{l}\text { Study Authors } \\
\text { (Reference) }\end{array}$ & NP Type and Details & $\begin{array}{c}\text { Cancer Cell } \\
\text { Line/Cytotoxicity (IC } \text { If }_{50} \text { of } \\
\text { NPs vs. Free CUR) }\end{array}$ & $\begin{array}{l}\text { Cellular Uptake of } \\
\text { CUR-NPs vs. Free CUR }\end{array}$ & Animal Model & $\begin{array}{l}\text { Treatment } \\
\text { Regimen }\end{array}$ & $\begin{array}{l}\text { In Vivo Antitumor } \\
\text { Activity }\end{array}$ & Toxicity \\
\hline [165] & $\begin{array}{c}\text { Polymeric NPs } \\
\text { (chitosan, sodium } \\
\text { tripolyphosphate) } \\
\text { PM: Ionic gelation } \\
\text { SZ: } 197 \pm 16.8 \mathrm{~nm} \\
\text { ZP: } 71 \pm 6.4 \mathrm{mV} \\
\text { EE: } \sim 85 \%\end{array}$ & $\begin{array}{c}\text { SiHa cells } \\
\text { NPs: } 97.27 \mu \mathrm{g} / \mathrm{mL} \\
\text { HeLa cells } \\
\text { NPs: } 88.41 \mu \mathrm{g} / \mathrm{mL} \\
\text { CasKi cells } \\
\text { NPs: } 81.48 \mu \mathrm{g} / \mathrm{mL} \\
\text { C33A cells } \\
\text { NPs: } 95.46 \mu \mathrm{g} / \mathrm{mL} \\
\text { IC } 50 \text { Values at } 72 \mathrm{~h} \\
\text { Value N/I for free CUR }\end{array}$ & $\begin{array}{c}\text { N/I } \\
\text { Among cells, NP uptake } \\
\text { over } 25 \text { h was CasKi > C33A } \\
>\text { HeLa > SiHa }\end{array}$ & - & - & - & - \\
\hline [166] & $\begin{array}{c}\text { Polymeric NPs } \\
\text { (PLGA, PVA, poly(l-lysine)) } \\
\text { PM, SZ, ZP, EE: N/I }\end{array}$ & $\begin{array}{c}\text { Caski cells } \\
\text { and } \\
\text { SiHa cells } \\
\mathrm{IC}_{50}: \mathrm{N} / \mathrm{I} \\
\uparrow \text { cytotoxicity for NPs }\end{array}$ & $\uparrow$ for NPs & $\begin{array}{l}\text { Female NOD scid } \\
\text { gamma mice } \\
\text { Caski cells }\left(4 \times 10^{6}\right. \\
\text { cells, injection into } \\
\text { cervix) } \\
\text { TV: } 200 \mathrm{~mm}^{3} \\
\text { (maximum tumor } \\
\text { burden allowed } \\
\text { post treatment: } \\
1100 \mathrm{~mm}^{3} \text { ) }\end{array}$ & $\begin{array}{c}100 \mu \mathrm{g} \\
\begin{array}{c}\text { intra-tumoral } \\
\text { injection }\end{array}\end{array}$ & $\begin{array}{c}\text { Changes in TV } \\
\text { NPs: } 637 \pm 68 \mathrm{~mm}^{3} \\
\text { Free CUR: } 816 \pm \\
94 \mathrm{~mm}^{3}\end{array}$ & $\mathrm{~N} / \mathrm{I}$ \\
\hline [167] & $\begin{array}{c}\text { Polymeric NPs } \\
\text { (Chitosan, alginate, sodium } \\
\text { tripolyphosphate) } \\
\text { PM: Ultrasonic-assisted } \\
\text { method } \\
\text { SZ: } 50 \mathrm{~nm} \\
\text { ZP: N/I } \\
\text { EE: } 70 \%\end{array}$ & $\begin{array}{c}\text { HeLa cells } \\
\mathrm{IC}_{50}: \mathrm{N} / \mathrm{I} \\
\uparrow \text { cytotoxicity for NPs }\end{array}$ & $\mathrm{N} / \mathrm{I}$ & ND & ND & ND & ND \\
\hline [168] & $\begin{array}{c}\text { Micelles } \\
\text { (Pectin) } \\
\text { PM: Self-assembly method } \\
\text { SZ: 70-190 nm } \\
\text { ZP: N/I } \\
\text { EE: N/I }\end{array}$ & $\begin{array}{l}\text { HeLa cells NPs: } 14.1 \pm 3.0 \mu \mathrm{M} \\
\text { Free CUR: } 40.9 \pm 2.6\end{array}$ & $\mathrm{~N} / \mathrm{I}$ & ND & ND & ND & ND \\
\hline
\end{tabular}


Table 1. Cont.

\begin{tabular}{|c|c|c|c|c|c|c|c|}
\hline $\begin{array}{l}\text { Study Authors } \\
\text { (Reference) }\end{array}$ & NP Type and Details & $\begin{array}{c}\text { Cancer Cell } \\
\text { Line/Cytotoxicity (IC } \text { If }_{50} \text { of } \\
\text { NPs vs. Free CUR) }\end{array}$ & $\begin{array}{l}\text { Cellular Uptake of } \\
\text { CUR-NPs vs. Free CUR }\end{array}$ & Animal Model & $\begin{array}{l}\text { Treatment } \\
\text { Regimen }\end{array}$ & $\begin{array}{l}\text { In Vivo Antitumor } \\
\text { Activity }\end{array}$ & Toxicity \\
\hline [169] & $\begin{array}{c}\text { Silica/titania mesoporous NPs } \\
\text { (coated with } \\
\text { polyethylenimine-FA) } \\
\text { PM: Hydrolysis, } \\
\text { condensation reactions, and } \\
\text { surface functionalization. } \\
\text { Drug loading (solvent } \\
\text { deposition) } \\
\text { SZ: } 173 \pm 15 \mathrm{~nm} \\
\text { ZP: } \mathrm{N} / \mathrm{I} \\
\text { EE: } 43.36 \pm 0.32 \%\end{array}$ & $\begin{array}{c}\text { HeLa cells } \\
\uparrow \text { cytotoxicity for NPs } \\
\text { (synergetic } \\
\text { chemo-sonodynamic therapy } \\
\text { observed) }\end{array}$ & $\mathrm{N} / \mathrm{I}$ & ND & ND & ND & ND \\
\hline$[170]$ & $\begin{array}{c}\text { Liposomes } \\
\text { (DSPE, PEG } \text { PEo0, }^{2} \text { FA, SPC, } \\
\text { cholesterol) } \\
\text { PM: Thin-film hydration } \\
\text { SZ: } 112.3 \pm 4.6 \mathrm{~nm} \\
\text { ZP: }-15.3 \pm 1.4 \mathrm{mV} \\
\text { EE: } 87.6 \%\end{array}$ & $\begin{array}{c}\text { HeLa cells } \\
\text { NPs: } 0.82 \mu \mathrm{g} / \mathrm{mL} \\
\text { Free CUR: } 1.47 \mu \mathrm{g} / \mathrm{mL}\end{array}$ & $\begin{array}{c}\uparrow \\
\text { NPs-66.4 } \\
\text { Free CUR-5.7 } \\
\text { F. } \\
\text { F }\end{array}$ & $\begin{array}{c}\text { Female BALB } / \mathrm{c} \\
\text { mice } \\
\left(\sim 5 \times 10^{6} \text { cells in }\right. \\
100 \mu \mathrm{LBBS} \text {, lower } \\
\text { right flank }) \\
\text { TV: } 100-150 \mathrm{~mm}^{3}\end{array}$ & $\begin{array}{l}25 \mathrm{mg} / \mathrm{kg} \text { CUR, on } \\
\text { alternate days for } \\
\text { three weeks }\end{array}$ & $\begin{array}{c}\text { Final TV } \\
\text { NPs: } 77.3 \pm 56.5 \mathrm{~mm}^{3} \\
\text { Free CUR: } 634.3 \pm \\
67.4 \mathrm{~mm}^{3}\end{array}$ & $\begin{array}{c}\text { No obvious acute } \\
\text { toxicity }\end{array}$ \\
\hline$[171]$ & $\begin{array}{c}\text { Nano-niosomes } \\
\left(\mathrm{Fe}_{3} \mathrm{O}_{4}, \text { PLGA, PEG, FA) }\right. \\
\text { PM: Double emulsion } \\
\text { method (W/O/W) and } \\
\text { vacuum drying } \\
\text { SZ: } 190.4 \pm 5.3 \mathrm{~nm} \\
\text { ZP: N/I } \\
\text { EE: } 86.46 \%\end{array}$ & $\begin{array}{l}\mathrm{HeLa} 229 \text { cells } \\
\mathrm{IC}_{50}: \mathrm{N} / \mathrm{I}\end{array}$ & $\uparrow$ & - & - & - & - \\
\hline [172] & $\begin{array}{c}\text { Micelles } \\
\text { PM: Co-assembly of CUR } \\
\text { and cystine/lysine-bridged } \\
\text { peptide (CBP/LBP) } \\
\text { SZ: } 250 \mathrm{~nm} \\
\text { ZP: N/I } \\
\text { EE: } 63.44 \%\end{array}$ & $\begin{array}{c}\text { HeLa cells } \\
\uparrow \text { cytotoxicity for NPs (but } \\
\text { higher with the CBP) } \\
\mathrm{IC}_{50}: \mathrm{N} / \mathrm{I}\end{array}$ & $\begin{array}{l}\uparrow \text { for NPs (but higher with } \\
\text { the CBP) }\end{array}$ & $\begin{array}{l}\text { Female } \\
\text { BALB/c nude mice } \\
\text { bearing HeLa cells } \\
\text { Treatment was } \\
\text { started on the } \\
\text { 10th day when the } \\
\text { tumor volume } \\
\text { reached } 100 \mathrm{~mm} 3\end{array}$ & $\begin{array}{c}2.5 \mathrm{mg} / \mathrm{kg} \\
\text { intravenous } \\
\text { injection into tail, } \\
\text { every three days for } \\
14 \text { days }\end{array}$ & $\begin{array}{c}\text { TGI } \\
\text { NPs (CBP): } 69.12 \% \\
\text { NPs (LBP): } \\
10.66 \% \\
\text { Free CUR: } 36.14 \%\end{array}$ & $\begin{array}{c}\text { NPs: Minimal } \\
\text { effects on healthy } \\
\text { tissues } \\
\text { Free CUR: } \\
\text { Apoptosis in liver, } \\
\text { kidney, spleen } \\
\text { All formulations: } \\
\text { No significant } \\
\text { Effect on body } \\
\text { weight }\end{array}$ \\
\hline
\end{tabular}


Table 1. Cont.

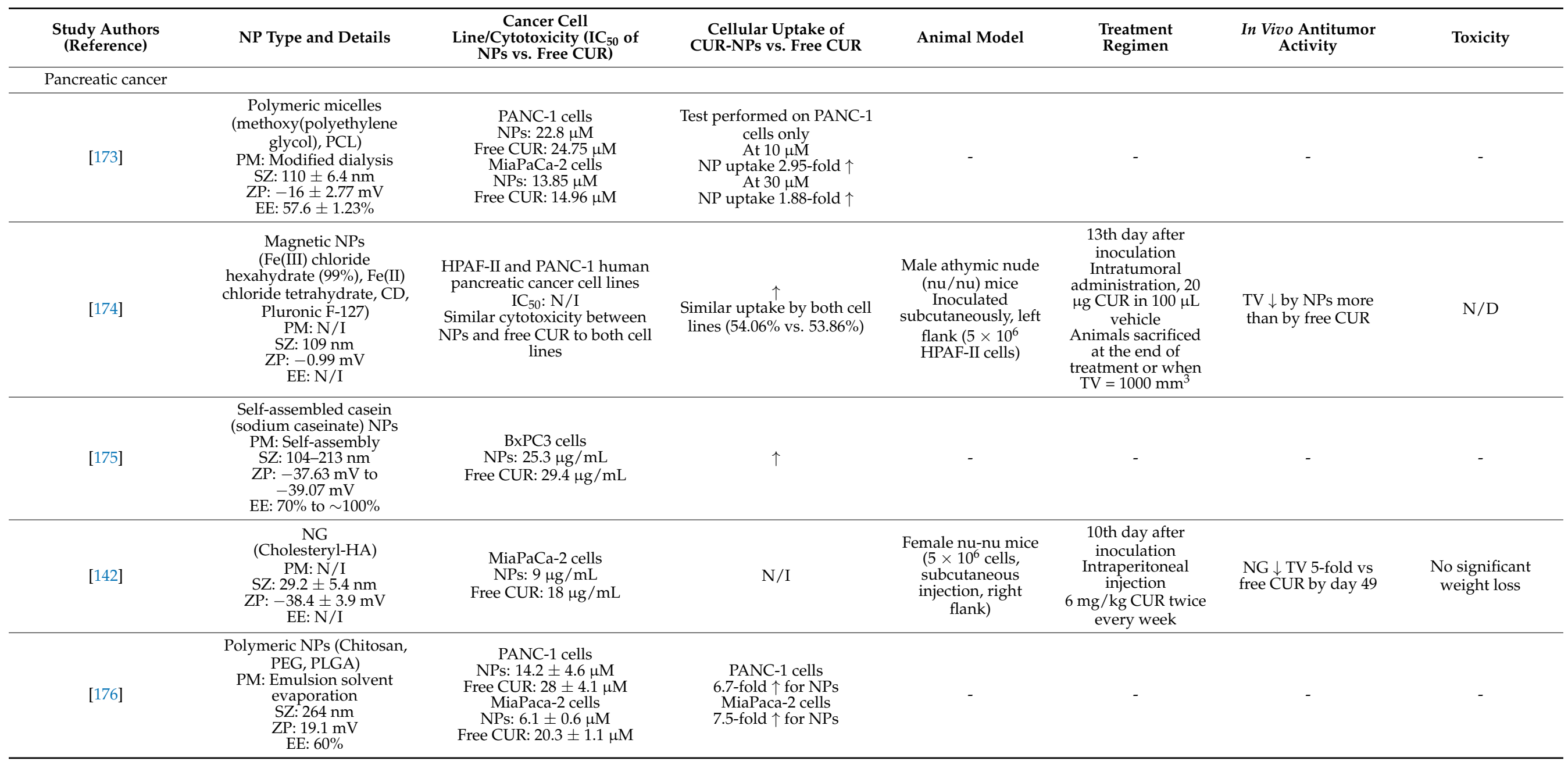


Table 1. Cont.

\begin{tabular}{|c|c|c|c|c|c|c|c|}
\hline $\begin{array}{l}\text { Study Authors } \\
\text { (Reference) }\end{array}$ & NP Type and Details & $\begin{array}{c}\text { Cancer Cell } \\
\text { Line/Cytotoxicity (IC } 50 \text { of } \\
\text { NPs vs. Free CUR) }\end{array}$ & $\begin{array}{l}\text { Cellular Uptake of } \\
\text { CUR-NPs vs. Free CUR }\end{array}$ & Animal Model & $\begin{array}{l}\text { Treatment } \\
\text { Regimen }\end{array}$ & $\begin{array}{l}\text { In Vivo Antitumor } \\
\text { Activity }\end{array}$ & Toxicity \\
\hline [177] & $\begin{array}{l}\text { Chitosan-coated lipid NPs } \\
\text { (chitosan, stearoyl chloride, } \\
\text { cholesterol) } \\
\text { PM: Cold dilution of } \\
\text { microemulsion } \\
\text { SZ: } 190.6 \pm 1.5 \mathrm{~nm} \\
\text { ZP: } 2.10 \pm 0.51 \mathrm{mV} \\
\text { EE: } 73.4 \pm 0.3 \%\end{array}$ & $\begin{array}{c}\text { PANC- } 1 \text { cell lines } \\
\text { IC } 50: N / I \\
\uparrow \text { cytotoxicity of NPs at } 5 \text { and } \\
10 \mu \mathrm{M} \text { CUR concentration }\end{array}$ & - & - & - & - & - \\
\hline [178] & $\begin{array}{c}\text { SLNs } \\
\text { (trilaurin) } \\
\text { PM: Cold dilution of } \\
\text { microemulsion } \\
\text { SZ: } 200 \mathrm{~nm} \\
\text { ZP: }-10.06 \pm 2.66 \mathrm{mV} \\
\text { EE: } 75 \pm 1.0 \%\end{array}$ & $\begin{array}{l}\text { CFPAC- } 1 \text { and PANC- } 1 \text { cells } \\
\text { IC } 5 \text { : N/I } \\
\uparrow \text { cytotoxicity of NPs }\end{array}$ & - & - & - & - & - \\
\hline
\end{tabular}

Abbreviations: CD, cyclodextrin; CUR, curcumin; EE, encapsulation efficiency; FA, folic acid; HA, hyaluronic acid; IC 50 : half-maximal inhibitory concentration; $\mathrm{N} / \mathrm{D}$, not determined; N/I, not indicated; NG, nanogel; NP, nanoparticle; PCL, polycaprolactone; PEG, polyethylene glycol; PM, preparation method; ROS, reactive oxygen species; SZ, size; TGI, tumor growth inhibition; TV, tumor volume; ZP, zeta potential. 


\section{Synergistic Effect of CUR-NPs with Other Anticancer Drugs}

Combination drug treatment is a popular strategy that can be beneficial in overcoming drug resistance and dose-limiting toxicity, which are typical concerns associated with the management of cancer [179]. Some studies have shown that NPs containing CUR in addition to other drugs can have synergistic anticancer effects. For instance, NPs co-loaded with CUR and doxorubicin have been shown to be effective against lung cancer [180]. In other studies, NPs containing CUR and paclitaxel [181], methotrexate [182], GANT61 [183], or doxorubicin [184] have been shown to be effective against breast cancer. It has also been found that CUR and docetaxel [185] or CUR and cabazitaxel [186] have synergistic effects against prostate cancer. Finally, it has been revealed that CUR and oxaliplatin [187], 5-fluorouracil [188], camptothecin [189,190], chrysin [191], doxorubicin [192,193], or cetuximab [194] may synergistically inhibit the growth of colon cancer cells. From the foregoing, it is possible that the abovementioned cancers may be better managed with NPs loaded with both CUR and the other anticancer drugs. However, clinical trials are required to clarify the effectiveness of these proposed combination therapies.

\section{Clinical Trials Conducted on CUR-NPs}

Pharmaceutical formulations that show promise in preclinical studies must be evaluated in clinical trials, because preclinical findings may not be necessarily be reflected in humans.

There is only a handful of clinical trials (ongoing or completed) covering the therapeutic evaluation of CUR-NPs, with trials related to CUR-NPs for cancer management being even more scarce. A clinical trial has been conducted on a CUR-NP formulation called THERACURMIN, in which six healthy volunteers were orally administered two doses (150 and $210 \mathrm{mg}$ ) of the preparation. The trial showed a high CUR bioavailability following administration to human subjects. However, the subjects were not administered free CUR [195]. It was also found from a randomized, placebo-controlled, double-blind phase I dose escalation study performed in healthy participants $(n=50$, male and female) that short-term administration of intravenous liposomal CUR $\left(<0.2 \mu \mathrm{m}\right.$; dose, $\left.120 \mathrm{mg} / \mathrm{m}^{2}\right)$ may be safe but can cause changes in red blood cell morphology [196].

A clinical trial on the use of plant exosomes (50-100 nm) to deliver CUR to colon tumors and normal colon tissue started in January 2011. Subjects are being administered CUR tablets, CUR conjugated with plant exosomes, or no treatment, with the primary outcome measure being CUR concentration in normal and cancerous tissue. The study is ongoing and therefore no outcomes have been published yet (NCT number: NCT01294072, 2011).

CUR-containing nanostructured lipid particles (100 mg p.o. bid daily) have been evaluated in an open-label phase II clinical trial (50 colorectal cancer patients with unresectable metastasis) in addition to standard chemotherapy treatment (Avastin/FOLFIRI [folinic acid, fluorouracil, irinotecan]). The primary end point was to evaluate progression-free survival (time frame, 2 years) (NCT number: NCT02439385, 2015).

Saadipoor and colleagues [197] have conducted a randomized controlled trial to assess the benefit of CUR-loaded nanomicelles (10 nm, 100\% EE) in radiation-induced proctitis in prostate cancer patients undergoing radiotherapy. Unfortunately, the CUR formulation was not found to be efficacious in the patients.

From the foregoing, it is very evident that more evaluations of CUR nanoformulations in human subjects are required. This is important because several studies have shown promising anticancer benefits of some CUR-NPs in vitro and in animal models.

\section{Conclusions}

CUR has received extensive interest for its diverse health benefits in general and its anticancer effects in particular. It has been proposed as a natural and effective anticancer agent with mild to no side effects. A plethora of studies have shown multiple anticancer mechanisms of CUR and the synergistic effects of combining CUR with other anticancer agents. Since poor bioavailability is the main obstacle in the use of CUR for cancer treat- 
ment, research has been devoted towards fabricating advanced drug delivery systems to improve CUR stability and bioavailability. A good number of in vitro, in vivo, and clinical studies have shown that CUR has an anticancer effect, and that NPs improve the oral bioavailability, stability, and targeted delivery of CUR, which could make CUR-NPs useful in cancer management.

Author Contributions: Conceptualization, H.A., E.A. and R.S.; writing-original draft preparation, H.A., E.A. and R.S.; writing-review and editing, H.A., E.A., R.S. and N.B.; table and figure preparation, H.A., R.S. and N.B. All authors have read and agreed to the published version of the manuscript.

Funding: This research received no external funding.

Informed Consent Statement: Not applicable.

Conflicts of Interest: The authors declare no conflict of interest.

\section{References}

1. Sung, H.; Ferlay, J.; Siegel, R.L.; Laversanne, M.; Soerjomataram, I.; Jemal, A.; Bray, F. Global Cancer Statistics 2020: GLOBOCAN Estimates of Incidence and Mortality Worldwide for 36 Cancers in 185 Countries. CA Cancer J. Clin. 2021, 71, 209-249. [CrossRef]

2. Watanabe, T.; Muro, K.; Ajioka, Y.; Hashiguchi, Y.; Ito, Y.; Saito, Y.; Hamaguchi, T.; Ishida, H.; Ishiguro, M.; Ishihara, S. Japanese Society for Cancer of the Colon and Rectum (JSCCR) guidelines 2010 for the treatment of colorectal cancer. Int. J. Clin. Oncol. 2012, 17, 1-29. [CrossRef] [PubMed]

3. Jong, K.H. Controversial issues in radiotherapy for rectal cancer: A systematic review. Radiat. Oncol. J. 2017, 35, 295-305. [CrossRef]

4. Wu, X.; Zhang, J.; He, X.; Wang, C.; Lian, L.; Liu, H.; Wang, J.; Lan, P. Postoperative Adjuvant Chemotherapy for Stage II Colorectal Cancer: A Systematic Review of 12 Randomized Controlled Trials. J. Gastrointest. Surg. 2012, 16, 646-655. [CrossRef] [PubMed]

5. Masoud, V.; Pagès, G. Targeted therapies in breast cancer: New challenges to fight against resistance. World J. Clin. Oncol. 2017, 8, 120-134. [CrossRef] [PubMed]

6. Padma, V.V. An overview of targeted cancer therapy. BioMedicine 2015, 5, 1-6. [CrossRef] [PubMed]

7. Cohen, L.; Hack, T.F.; De Moor, C.; Katz, J.; Goss, P.E. The Effects of Type of Surgery and Time on Psychological Adjustment in Women After Breast Cancer Treatment. Ann. Surg. Oncol. 2000, 7, 427-434. [CrossRef]

8. Crawford, S.C.; Vasey, P.A.; Paul, J.; Hay, A.; Davis, J.A.; Kaye, S.B. Does aggressive surgery only benefit patients with less advanced ovarian cancer? Results from an international comparison within the SCOTROC-1 trial. J. Clin. Oncol. 2005, 23, 8802-8811. [CrossRef]

9. Gamba, A.; Romano, M.; Grosso, L.M.; Tamburini, M.; Cantú, G.; Molinari, R.; Ventafridda, V. Psychosocial adjustment of patients surgically treated for head and neck cancer. Head Neck 1992, 14, 218-223. [CrossRef]

10. Farrell, C.; Brearley, S.G.; Pilling, M.; Molassiotis, A. The impact of chemotherapy-related nausea on patients' nutritional status, psychological distress and quality of life. Support. Care Cancer 2013, 21, 59-66. [CrossRef]

11. Groopman, J.E.; Itri, L.M. Chemotherapy-induced anemia in adults: Incidence and treatment. J. Natl. Cancer Inst. 1999, 91, 1616-1634. [CrossRef] [PubMed]

12. Molassiotis, A.; Russell, W.; Hughes, J.; Breckons, M.; Lloyd-Williams, M.; Richardson, J.; Hulme, C.; Brearley, S.G.; Campbell, M.; Garrow, A.; et al. The effectiveness of acupressure for the control and management of chemotherapy-related acute and delayed nausea: A randomized controlled trial. J. Pain Symptom Manag. 2014, 47, 12-25. [CrossRef] [PubMed]

13. Moorthi, C.; Kathiresan, K. Curcumin-Piperine/Curcumin-Quercetin/Curcumin-Silibinin dual drug-loaded nanoparticulate combination therapy: A novel approach to target and treat multidrug-resistant cancers. J. Med. Hypotheses Ideas 2013, 7 , 15-20. [CrossRef]

14. Jagetia, G.; Aggarwal, B.B. Spicing Up of the Immune System by Curcumin. J. Clin. Immunol. 2007, 27, 19-35. [CrossRef] [PubMed]

15. Hua, S. Orally administered liposomal formulations for colon targeted drug delivery. Front. Pharmacol. 2014, 5, 1-4. [CrossRef] [PubMed]

16. Prasad, S.; Gupta, S.C.; Tyagi, A.K.; Aggarwal, B.B. Curcumin, a component of golden spice: From bedside to bench and back. Biotechnol. Adv. 2014, 32, 1053-1064. [CrossRef]

17. Chuah, L.H.; Billa, N.; Roberts, C.J.; Burley, J.C.; Manickam, S. Curcumin-containing chitosan nanoparticles as a potential mucoadhesive delivery system to the colon. Pharm. Dev. Technol. 2013, 18, 591-599. [CrossRef]

18. Hewlings, S.J.; Kalman, D.S. Curcumin: A Review of Its' Effects on Human Health. Foods 2017, 6, 92. [CrossRef]

19. Katona, B.W.; Weiss, J.M. Chemoprevention of Colorectal Cancer. Gastroenterology 2020, 158, 368-388. [CrossRef]

20. Anand, P.; Kunnumakkara, A.B.; Newman, R.A.; Aggarwal, B.B. Bioavailability of curcumin: Problems and promises. Mol. Pharm. 2007, 4, 807-818. [CrossRef]

21. Prasad, S.; Aggarwal, B.B. Turmeric, the Golden Spice: From Traditional Medicine to Modern Medicine; CRC Press: Boca Raton, FL, USA, 2011; pp. 263-288. 
22. Wilken, R.; Veena, M.S.; Wang, M.B.; Srivatsan, E.S. Curcumin: A review of anti-cancer properties and therapeutic activity in head and neck squamous cell carcinoma. Mol. Cancer 2011, 10, 1-19. [CrossRef]

23. Ibáñez, M.D.; Blázquez, M.A. Curcuma longa L. Rhizome Essential Oil from Extraction to Its Agri-Food Applications. A Review. Plants 2021, 10, 44. [CrossRef] [PubMed]

24. Nasery, M.M.; Abadi, B.; Poormoghadam, D.; Zarrabi, A.; Keyhanvar, P.; Khanbabaei, H.; Ashrafizadeh, M.; Mohammadinejad, R.; Tavakol, S.; Sethi, G. Curcumin Delivery Mediated by Bio-Based Nanoparticles: A Review. Molecules 2020, 25, 689. [CrossRef]

25. Horev, L.; Ramot, Y.; Klapholz, L. Yellow Feet in a Patient with Breast and Thyroid Carcinoma, Due to Oral Intake of Turmeric Drug Saf. Case Rep. 2015, 2, 4. [CrossRef]

26. Bernabé-Pineda, M.; Ramírez-Silva, M.T.; Romero-Romo, M.; González-Vergara, E.; Rojas-Hernández, A. Determination of acidity constants of curcumin in aqueous solution and apparent rate constant of its decomposition. Spectrochim. Acta Part A Mol. Biomol. Spectrosc. 2004, 60, 1091-1097. [CrossRef]

27. Nair, K.L.; Thulasidasan, A.K.T.; Deepa, G.; Anto, R.J.; Kumar, G.S.V. Purely aqueous PLGA nanoparticulate formulations of curcumin exhibit enhanced anticancer activity with dependence on the combination of the carrier. Int. J. Pharm. 2012, 425, 44-52. [CrossRef]

28. Park, S.; Lee, S.Y. Significant enhancement of curcumin photoluminescence by a photosensitizing organogel: An optical sensor for pyrrole detection. Sensors Actuators B Chem. 2015, 220, 318-325. [CrossRef]

29. Priyadarsini, K.I. Photophysics, photochemistry and photobiology of curcumin: Studies from organic solutions, bio-mimetics and living cells. J. Photochem. Photobiol. C Photochem. Rev. 2009, 10, 81-95. [CrossRef]

30. Yallapu, M.M.; Nagesh, P.K.B.; Jaggi, M.; Chauhan, S.C. Therapeutic Applications of Curcumin Nanoformulations. AAPS J. 2015, 17, 1341-1356. [CrossRef]

31. Barzegar, A. The role of electron-transfer and $\mathrm{H}$-atom donation on the superb antioxidant activity and free radical reaction of curcumin. Food Chem. 2012, 135, 1369-1376. [CrossRef]

32. Tønnesen, H.H.; Másson, M.; Loftsson, T. Studies of curcumin and curcuminoids. XXVII. Cyclodextrin complexation: Solubility, chemical and photochemical stability. Int. J. Pharm. 2002, 244, 127-135. [CrossRef]

33. Shen, L.; Ji, H.F. The pharmacology of curcumin: Is it the degradation products? Trends Mol. Med. 2012, 18, 138-144. [CrossRef] [PubMed]

34. Priyadarsini, K.I. The Chemistry of Curcumin: From Extraction to Therapeutic Agent. Molecules 2014, 19, 20091-20112. [CrossRef]

35. Reddy, R.C.; Vatsala, P.G.; Keshamouni, V.G.; Padmanaban, G.; Rangarajan, P.N. Curcumin for malaria therapy. Biochem. Biophys. Res. Commun. 2005, 326, 472-474. [CrossRef] [PubMed]

36. Manohar, S.; Khan, S.I.; Kandi, S.K.; Raj, K.; Sun, G.; Yang, X.; Calderon Molina, A.D.; Ni, N.; Wang, B.; Rawat, D.S. Synthesis, antimalarial activity and cytotoxic potential of new monocarbonyl analogues of curcumin. Bioorganic Med. Chem. Lett. 2013, 23, 112-116. [CrossRef] [PubMed]

37. Ghosh, A.; Banerjee, T.; Bhandary, S.; Surolia, A. Formulation of nanotized curcumin and demonstration of its antimalarial efficacy. Int. J. Nanomed. 2014, 9, 5373-5387. [CrossRef]

38. Ghaffari, S.B.; Sarrafzadeh, M.H.; Salami, M.; Khorramizadeh, M.R. A pH-sensitive delivery system based on N-succinyl chitosan-ZnO nanoparticles for improving antibacterial and anticancer activities of curcumin. Int. J. Biol. Macromol. 2020, 151, 428-440. [CrossRef]

39. Cheng, Y.; Zhang, Y.; Deng, W.; Hu, J. Antibacterial and anticancer activities of asymmetric lollipop-like mesoporous silica nanoparticles loaded with curcumin and gentamicin sulfate. Colloids Surfaces B Biointerfaces 2020, 186, 110744. [CrossRef]

40. Zandi, K.; Ramedani, E.; Khosro, M.; Tajbakhsh, S.; Dailami, I.; Rastian, Z.; Fouladvand, M.; Yousefi, F.; Farshadpour, F. Natural Product Communications Evaluation of Antiviral Activities of Curcumin Derivatives. Nat. Prod. Commun. 2010, 5, 8-11.

41. Singh, R.K.; Rai, D.; Yadav, D.; Bhargava, A.; Balzarini, J.; De Clercq, E. Synthesis, antibacterial and antiviral properties of curcumin bioconjugates bearing dipeptide, fatty acids and folic acid. Eur. J. Med. Chem. 2010, 45, 1078-1086. [CrossRef]

42. Mathew, D.; Hsu, W.L. Antiviral potential of curcumin. J. Funct. Foods 2018, 40, 692-699. [CrossRef]

43. Zorofchian Moghadamtousi, S.; Abdul Kadir, H.; Hassandarvish, P.; Tajik, H.; Abubakar, S.; Zandi, K. A review on antibacterial, antiviral, and antifungal activity of curcumin. Biomed Res. Int. 2014, 2014, 186864. [CrossRef] [PubMed]

44. Khalil, O.A.K.; De Faria Oliveira, O.M.M.; Vellosa, J.C.R.; De Quadros, A.U.; Dalposso, L.M.; Karam, T.K.; Mainardes, R.M.; Khalil, N.M. Curcumin antifungal and antioxidant activities are increased in the presence of ascorbic acid. Food Chem. 2012, 133, 1001-1005. [CrossRef]

45. Somparn, P.; Phisalaphong, C.; Nakornchai, S.; Unchern, S.; Morales, N.P. Comparative antioxidant activities of curcumin and its demethoxy and hydrogenated derivatives. Biol. Pharm. Bull. 2007, 30, 74-78. [CrossRef] [PubMed]

46. Jang, M.H.; Piao, X.L.; Kim, J.M.; Kwon, S.W.; Park, J.H. Inhibition of cholinesterase and amyloid-\&bgr; aggregation by resveratrol oligomers from Vitis amurensis. Phyther. Res. 2008, 22, 544-549. [CrossRef]

47. Sonkaew, P.; Sane, A.; Suppakul, P. Antioxidant activities of curcumin and ascorbyl dipalmitate nanoparticles and their activities after incorporation into cellulose-based packaging films. J. Agric. Food Chem. 2012, 60, 5388-5399. [CrossRef]

48. Meng, B.; Li, J.; Cao, H. Antioxidant and Antiinflammatory Activities of Curcumin on Diabetes Mellitus and its Complications. Curr. Pharm. Des. 2013, 19, 2101-2113. [CrossRef]

49. Yu, Y.; Shen, Q.; Lai, Y.; Park, S.Y.; Ou, X.; Lin, D.; Jin, M.; Zhang, W. Anti-inflammatory effects of curcumin in microglial cells. Front. Pharmacol. 2018, 9, 1-10. [CrossRef] 
50. Gutierres, V.O.; Campos, M.L.; Arcaro, C.A.; Assis, R.P.; Baldan-Cimatti, H.M.; Peccinini, R.G.; Paula-Gomes, S.; Kettelhut, I.C.; Baviera, A.M.; Brunetti, I.L. Curcumin Pharmacokinetic and Pharmacodynamic Evidences in Streptozotocin-Diabetic Rats Support the Antidiabetic Activity to Be via Metabolite(s). Evid.-Based Complement. Altern. Med. 2015, 2015, 678218. [CrossRef]

51. Akolade, J.O.; Oloyede, H.O.B.; Onyenekwe, P.C. Encapsulation in chitosan-based polyelectrolyte complexes enhances antidiabetic activity of curcumin. J. Funct. Foods 2017, 35, 584-594. [CrossRef]

52. Sharma, A.; Yadav, A.; Gupta, N.; Sharma, S.; Kakkar, R.; Cwiklinski, K.; Quaye, E.; Mahajan, S.D.; Schwartz, S.A.; Kumar Sharma, R. Multifunctional mesoporous curcumin encapsulated iron-phenanthroline nanocluster: A new Anti-HIV agent. Colloids Surf. B Biointerfaces 2019, 180, 289-297. [CrossRef]

53. Praditya, D.; Kirchhoff, L.; Brüning, J.; Rachmawati, H.; Steinmann, J.; Steinmann, E. Anti-infective properties of the golden spice curcumin. Front. Microbiol. 2019, 10, 1-16. [CrossRef] [PubMed]

54. Rai, M.; Ingle, A.P.; Pandit, R.; Paralikar, P.; Anasane, N.; Santos, C.A. Dos Curcumin and curcumin-loaded nanoparticles: Antipathogenic and antiparasitic activities. Expert Rev. Anti. Infect. Ther. 2020, 18, 367-379. [CrossRef] [PubMed]

55. Fan, Y.; Yi, J.; Zhang, Y.; Yokoyama, W. Improved Chemical Stability and Antiproliferative Activities of Curcumin-Loaded Nanoparticles with a Chitosan Chlorogenic Acid Conjugate. J. Agric. Food Chem. 2017, 65, 10812-10819. [CrossRef] [PubMed]

56. Chen, S.; Wu, J.; Tang, Q.; Xu, C.; Huang, Y.; Huang, D.; Luo, F.; Wu, Y.; Yan, F.; Weng, Z.; et al. Nano-micelles based on hydroxyethyl starch-curcumin conjugates for improved stability, antioxidant and anticancer activity of curcumin. Carbohydr. Polym. 2020, 228, 115398. [CrossRef]

57. Bolat, Z.B.; Islek, Z.; Demir, B.N.; Yilmaz, E.N.; Sahin, F.; Ucisik, M.H. Curcumin- and Piperine-Loaded Emulsomes as Combinational Treatment Approach Enhance the Anticancer Activity of Curcumin on HCT116 Colorectal Cancer Model. Front. Bioeng. Biotechnol. 2020, 8, 1-21. [CrossRef] [PubMed]

58. Allegra, A.; Innao, V.; Russo, S.; Gerace, D.; Alonci, A.; Musolino, C. Anticancer Activity of Curcumin and Its Analogues: Preclinical and Clinical Studies. Cancer Investig. 2017, 35, 1-22. [CrossRef]

59. Jahanban-Esfahlan, R.; Seidi, K.; Manjili, M.H.; Jahanban-Esfahlan, A.; Javaheri, T.; Zare, P. Tumor Cell Dormancy: Threat or Opportunity in the Fight against Cancer. Cancers 2019, 11, 1207. [CrossRef]

60. Igal, R.A. Stearoyl-coa desaturase-1: A novel key player in the mechanisms of cell proliferation, programmed cell death and transformation to cancer. Carcinogenesis 2010, 31, 1509-1515. [CrossRef]

61. Kanikarla-Marie, P.; Lam, M.; Menter, D.G.; Kopetz, S. Platelets, circulating tumor cells, and the circulome. Cancer Metastasis Rev. 2017, 36, 235-248. [CrossRef]

62. Singh, S.; Aggarwal, B.B. Activation of transcription factor NF-kB is suppressed by curcumin (diferulolylmethane). J. Biol. Chem. 1995, 270, 24995-25000. [CrossRef]

63. Mishra, A.; Kumar, R.; Tyagi, A.; Kohaar, I.; Hedau, S.; Bharti, A.C.; Sarker, S.; Dey, D.; Saluja, D.; Das, B. Curcumin modulates cellular AP-1, NF-kB, and HPV16 E6 proteins in oral cancer. Ecancermedicalscience 2015, 9, 1-12. [CrossRef] [PubMed]

64. Giri, R.K.; Rajagopal, V.; Kalra, V.K. Curcumin, the active constituent of turmeric, inhibits amyloid peptide-induced cytochemokine gene expression and CCR5-mediated chemotaxis of THP-1 monocytes by modulating early growth response-1 transcription factor. J. Neurochem. 2004, 91, 1199-1210. [CrossRef]

65. Mazidi, M.; Karimi, E.; Meydani, M.; Ghayour-Mobarhan, M.; Ferns, G.A. Potential effects of curcumin on peroxisome proliferatoractivated receptor- $\gamma$ in vitro and in vivo. World J. Methodol. 2016, 6, 112. [CrossRef] [PubMed]

66. Shehzad, A.; Lee, Y.S. Molecular mechanisms of curcumin action: Signal transduction. BioFactors 2013, 39, 27-36. [CrossRef] [PubMed]

67. Prasad, C.P.; Rath, G.; Mathur, S.; Bhatnagar, D.; Ralhan, R. Potent growth suppressive activity of curcumin in human breast cancer cells: Modulation of Wnt/ $\beta$-catenin signaling. Chem. Biol. Interact. 2009, 181, 263-271. [CrossRef]

68. Peng, X.; Dai, C.; Liu, Q.; Li, J.; Qiu, J. Curcumin attenuates on carbon tetrachloride-induced acute liver injury in mice via modulation of the Nrf2/HO-1 and TGF- $\beta 1 / \mathrm{Smad} 3$ pathway. Molecules 2018, 23, 215. [CrossRef] [PubMed]

69. Balstad, T.R.; Carlsen, H.; Myhrstad, M.C.W.; Kolberg, M.; Reiersen, H.; Gilen, L.; Ebihara, K.; Paur, I.; Blomhoff, R. Coffee, broccoli and spices are strong inducers of electrophile response element-dependent transcription in vitro and in vivo - Studies in electrophile response element transgenic mice. Mol. Nutr. Food Res. 2011, 55, 185-197. [CrossRef]

70. Choi, H.Y.; Lim, J.E.; Hong, J.H. Curcumin interrupts the interaction between the androgen receptor and Wnt/ $\beta$-catenin signaling pathway in LNCaP prostate cancer cells. Prostate Cancer Prostatic Dis. 2010, 13, 343-349. [CrossRef]

71. Shishodia, S.; Singh, T.; Chaturvedi, M.M. Modulation of transcription factors by curcumin. Adv. Exp. Med. Biol. 2007, 595, 127-148. [CrossRef]

72. Filippi, A.; Ciolac, O.A.; Ganea, C.; Mocanu, M.M. ERBB proteins as molecular target of dietary phytochemicals in malignant diseases. J. Oncol. 2017, 2017, 1532534. [CrossRef] [PubMed]

73. Soung, Y.H.; Chung, J. Curcumin inhibition of the functional interaction between integrin $\alpha 6 \beta 4$ and the epidermal growth factor receptor. Mol. Cancer Ther. 2011, 10, 883-891. [CrossRef] [PubMed]

74. Leu, T.H.; Maa, M.C. The molecular mechanisms for the antitumorigenic effect of curcumin. Curr. Med. Chem.-Anti-Cancer Agents 2002, 2, 357-370. [CrossRef]

75. Elmarakby, A.A.; Sullivan, J.C. Relationship between oxidative stress and inflammatory cytokines in diabetic nephropathy. Cardiovasc. Ther. 2012, 30, 49-59. [CrossRef] [PubMed]

76. Keyel, P.A. How is inflammation initiated? Individual influences of IL-1, IL-18 and HMGB1. Cytokine 2014, 69, 136-145. [CrossRef] [PubMed] 
77. Federico, A.; Morgillo, F.; Tuccillo, C.; Ciardiello, F.; Loguercio, C. Chronic inflammation and oxidative stress in human carcinogenesis. Int. J. Cancer 2007, 121, 2381-2386. [CrossRef]

78. Fernandes, J.V.; Fernandes, T.A.A.D.M.; de Azevedo, J.C.V.; Cobucci, R.N.O.; de Carvalho, M.G.F.; Andrade, V.S.; De Araújo, J.M.G. Link between chronic inflammation and human papillomavirus-induced carcinogenesis (Review). Oncol. Lett. 2015, 9, 1015-1026. [CrossRef]

79. Bhandarkar, S.S.; Arbiser, J.L. Curcumin as an inhibitor of angiogenesis. Mol. Targets Ther. Uses Curcumin Health Dis. 2007, 595, 185-195.

80. Kunnumakkara, A.B.; Anand, P.; Aggarwal, B.B. Curcumin inhibits proliferation, invasion, angiogenesis and metastasis of different cancers through interaction with multiple cell signaling proteins. Cancer Lett. 2008, 269, 199-225. [CrossRef] [PubMed]

81. Hubbard, A.K.; Rothlein, R. Intercellular adhesion molecule-1 (ICAM-1) expression and cell signaling cascades. Free Radic. Biol. Med. 2000, 28, 1379-1386. [CrossRef]

82. Hintzpeter, J.; Hornung, J.; Ebert, B.; Martin, H.J.; Maser, E. Curcumin is a tight-binding inhibitor of the most efficient human daunorubicin reductase-Carbonyl reductase 1. Chem. Biol. Interact. 2015, 234, 162-168. [CrossRef]

83. Menna, P.; Gonzalez Paz, O.; Chello, M.; Covino, E.; Salvatorelli, E.; Minotti, G. Anthracycline cardiotoxicity. Expert Opin. Drug Saf. 2012, 11, 21-36. [CrossRef] [PubMed]

84. Boušová, I.; Skálová, L.; Souček, P.; Matoušková, P. The modulation of carbonyl reductase 1 by polyphenols. Drug Metab. Rev. 2015, 47, 520-533. [CrossRef] [PubMed]

85. Duvoix, A.; Morceau, F.; Delhalle, S.; Schmitz, M.; Schnekenburger, M.; Galteau, M.M.; Dicato, M.; Diederich, M. Induction of apoptosis by curcumin: Mediation by glutathione S-transferase P1-1 inhibition. Biochem. Pharmacol. 2003, 66, 1475-1483. [CrossRef]

86. Blasius, R.; Duvoix, A.; Morceau, F.; Schnekenburger, M.; Delhalle, S.; Henry, E.; Dicato, M.; Diederich, M. Curcumin stability and its effect on glutathione S-transferase P1-1 mRNA expression in K562 cells. Ann. N. Y. Acad. Sci. 2004, 1030, 442-448. [CrossRef] [PubMed]

87. Naeini, M.B.; Momtazi, A.A.; Jaafari, M.R.; Johnston, T.P.; Barreto, G.; Banach, M.; Sahebkar, A. Antitumor effects of curcumin: A lipid perspective. J. Cell. Physiol. 2019, 234, 14743-14758. [CrossRef]

88. Maithilikarpagaselvi, N.; Sridhar, M.G.; Swaminathan, R.P.; Sripradha, R.; Badhe, B. Curcumin inhibits hyperlipidemia and hepatic fat accumulation in high-fructose-fed male Wistar rats. Pharm. Biol. 2016, 54, 2857-2863. [CrossRef]

89. Lee, J.; Im, Y.H.; Hae, H.J.; Joo, H.K.; Joon, O.P.; Kim, K.; Won, S.K.; Jin, S.A.; Chul, W.J.; Young, S.P.; et al. Curcumin inhibits interferon- $\alpha$ induced NF- $\mathrm{BB}$ and COX-2 in human A549 non-small cell lung cancer cells. Biochem. Biophys. Res. Commun. 2005, 334, 313-318. [CrossRef]

90. Frank, A.; Eric, M.P.; Robert, L.; Omid, C.F. Nanoparticles Technologies for Cancer Therapy. Handb. Exp. Pharmacol. 2010, $197,55-86$.

91. Wong, T.W.; Colombo, G.; Sonvico, F. Pectin matrix as oral drug delivery vehicle for colon cancer treatment. AAPS PharmSciTech 2011, 12, 201-214. [CrossRef]

92. Jahan, S.T.; Sadat, S.M.A.; Walliser, M.; Haddadi, A. Targeted Therapeutic Nanoparticles: An Immense Promise to Fight against Cancer. J. Drug Deliv. 2017, 2017, 9090325. [CrossRef] [PubMed]

93. Bertrand, N.; Wu, J.; Xu, X.; Kamaly, N.; Farokhzad, O.C. Cancer nanotechnology: The impact of passive and active targeting in the era of modern cancer biology. Adv. Drug Deliv. Rev. 2014, 66, 2-25. [CrossRef]

94. Danhier, F.; Feron, O.; Préat, V. To exploit the tumor microenvironment: Passive and active tumor targeting of nanocarriers for anti-cancer drug delivery. J. Control. Release 2010, 148, 135-146. [CrossRef] [PubMed]

95. Ventola, C.L. Progress in Nanomedicine: Approved and Investigational Nanodrugs. Pharm. Ther. 2017, 42, 742.

96. Attia, M.F.; Anton, N.; Wallyn, J.; Omran, Z.; Vandamme, T.F. An overview of active and passive targeting strategies to improve the nanocarriers efficiency to tumour sites. J. Pharm. Pharmacol. 2019, 71, 1185-1198. [CrossRef] [PubMed]

97. Romero, G.; Moya, S.E. Synthesis of organic nanoparticles. In Frontiers of Nanoscience; Elsevier Ltd.: Amsterdam, The Netherlands, 2012; Volume 4, pp. 115-141. ISBN 978-0-12-415769-9.

98. Lacour, S. Emerging Questions for Emerging Technologies: Is There a Law for the Nano? In Nanomaterials: A Danger or a Promise?: A Chemical and Biological Perspective; Brayner, R., Coradin, T., Fiévet, F., Eds.; Springer: London, UK, 2013; pp. 357-378, ISBN 9781447142133.

99. Sanoj Rejinold, N.; Muthunarayanan, M.; Chennazhi, K.P.; Nair, S.V.; Jayakumar, R. Curcumin loaded fibrinogen nanoparticles for cancer drug delivery. J. Biomed. Nanotechnol. 2011, 7, 521-534. [CrossRef] [PubMed]

100. Mohan Yallapu, M.; Ray Dobberpuhl, M.; Michele Maher, D.; Jaggi, M.; Chand Chauhan, S. Design of Curcumin loaded Cellulose Nanoparticles for Prostate Cancer. Curr. Drug Metab. 2011, 13, 120-128. [CrossRef] [PubMed]

101. Ndong Ntoutoume, G.M.A.; Granet, R.; Mbakidi, J.P.; Brégier, F.; Léger, D.Y.; Fidanzi-Dugas, C.; Lequart, V.; Joly, N.; Liagre, B.; Chaleix, V.; et al. Development of curcumin-cyclodextrin/cellulose nanocrystals complexes: New anticancer drug delivery systems. Bioorganic Med. Chem. Lett. 2016, 26, 941-945. [CrossRef]

102. Yallapu, M.M.; Khan, S.; Maher, D.M.; Ebeling, M.C.; Sundram, V.; Chauhan, N.; Ganju, A.; Balakrishna, S.; Gupta, B.K.; Zafar, N.; et al. Anti-cancer activity of curcumin loaded nanoparticles in prostate cancer. Biomaterials 2014, 35, 8635-8648. [CrossRef]

103. Rao, W.; Zhang, W.; Poventud-Fuentes, I.; Wang, Y.; Lei, Y.; Agarwal, P.; Weekes, B.; Li, C.; Lu, X.; Yu, J.; et al. Thermally responsive nanoparticle-encapsulated curcumin and its combination with mild hyperthermia for enhanced cancer cell destruction. Acta Biomater. 2014, 10, 831-842. [CrossRef] 
104. Thangavel, S.; Yoshitomi, T.; Sakharkar, M.K.; Nagasaki, Y. Redox nanoparticles inhibit curcumin oxidative degradation and enhance its therapeutic effect on prostate cancer. J. Control. Release 2015, 209, 110-119. [CrossRef]

105. Ke, X.; Tang, H.; Mao, H.Q. Effective encapsulation of curcumin in nanoparticles enabled by hydrogen bonding using flash nanocomplexation. Int. J. Pharm. 2019, 564, 273-280. [CrossRef]

106. Prostate, D.C.; Cells, C.; Tanaudommongkon, I.; Tanaudommongkon, A.; Prathipati, P. Curcumin nanoparticles and their cytotoxicity in docetaxel-resistant castration-resistant prostate cancer cells. Biomedicines 2020, 8, 253.

107. Rahman, S.; Cao, S.; Steadman, K.J.; Wei, M.; Parekh, H.S. Native and B-cyclodextrin-enclosed curcumin: Entrapment within liposomes and their in vitro cytotoxicity in lung and colon cancer. Drug Deliv. 2012, 19, 346-353. [CrossRef] [PubMed]

108. Wang, P.; Zhang, L.; Peng, H.; Li, Y.; Xiong, J.; Xu, Z. The formulation and delivery of curcumin with solid lipid nanoparticles for the treatment of on non-small cell lung cancer both in vitro and in vivo. Mater. Sci. Eng. C 2013, 33, 4802-4808. [CrossRef] [PubMed]

109. Li, S.; Fang, C.; Zhang, J.; Liu, B.; Wei, Z.; Fan, X.; Sui, Z.; Tan, Q. Catanionic lipid nanosystems improve pharmacokinetics and anti-lung cancer activity of curcumin. Nanomed. Nanotechnol. Biol. Med. 2016, 12, 1567-1579. [CrossRef]

110. Hoshikawa, A.; Nagira, M.; Tane, M.; Fukushige, K.; Tagami, T.; Ozeki, T. Preparation of curcumin-containing $\alpha-, \beta-$, and $\gamma$-cyclodextrin/ polyethyleneglycol-conjugated gold multifunctional nanoparticles and their in vitro cytotoxic effects on A549 cells. Biol. Pharm. Bull. 2018, 41, 908-914. [CrossRef] [PubMed]

111. Yin, H.; Zhang, H.; Liu, B. Superior anticancer efficacy of curcumin-loaded nanoparticles against lung cancer. Acta Biochim. Biophys. Sin. 2013, 45, 634-640. [CrossRef] [PubMed]

112. Luo, C.Q.; Xing, L.; Cui, P.F.; Qiao, J.B.; He, Y.J.; Chen, B.A.; Jin, L.; Jiang, H.L. Curcumin-coordinated nanoparticles with improved stability for reactive oxygen species-responsive drug delivery in lung cancer therapy. Int. J. Nanomed. 2017, 12, 855-869. [CrossRef]

113. Vijayakurup, V.; Thulasidasan, A.T.; Shankar, M.G.; Retnakumari, A.P.; Nandan, C.D.; Somaraj, J.; Antony, J.; Alex, V.V.; Vinod, B.S.; Liju, V.B.; et al. Chitosan encapsulation enhances the bioavailability and tissue retention of curcumin and improves its efficacy in preventing b[a]p-induced lung carcinogenesis. Cancer Prev. Res. 2019, 12, 225-236. [CrossRef]

114. Pandelidou, M.; Dimas, K.; Georgopoulos, A.; Hatziantoniou, S.; Demetzos, C. Preparation and characterization of lyophilised EGG PC liposomes incorporating curcumin and evaluation of its activity against colorectal cancer cell lines. J. Nanosci. Nanotechnol. 2011, 11, 1259-1266. [CrossRef]

115. Chen, Y.; Du, Q.; Guo, Q.; Huang, J.; Liu, L.; Shen, X.; Peng, J. A W/O emulsion mediated film dispersion method for curcumin encapsulated pH-sensitive liposomes in the colon tumor treatment. Drug Dev. Ind. Pharm. 2019, 45, 282-291. [CrossRef]

116. Gou, M.; Men, K.; Shi, H.; Xiang, M.; Zhang, J.; Song, J.; Long, J.; Wan, Y.; Luo, F.; Zhao, X.; et al. Curcumin-loaded biodegradable polymeric micelles for colon cancer therapy in vitro and in vivo. Nanoscale 2011, 3, 1558-1567. [CrossRef] [PubMed]

117. Wang, K.; Zhang, T.; Liu, L.; Wang, X.; Wu, P.; Chen, Z.; Ni, C.; Zhang, J.; Hu, F.; Huang, J. Novel micelle formulation of curcumin for enhancing antitumor activity and inhibiting colorectal cancer stem cells. Int. J. Nanomed. 2012, 7, 4487-4497. [CrossRef]

118. Raveendran, R.; Bhuvaneshwar, G.S.; Sharma, C.P. In vitro cytotoxicity and cellular uptake of curcumin-loaded Pluronic/ Polycaprolactone micelles in colorectal adenocarcinoma cells. J. Biomater. Appl. 2013, 27, 811-827. [CrossRef] [PubMed]

119. Yang, X.; Li, Z.; Wang, N.; Li, L.; Song, L.; He, T.; Sun, L.; Wang, Z.; Wu, Q.; Luo, N.; et al. Curcumin-encapsulated polymeric micelles suppress the development of colon cancer in vitro and in vivo. Sci. Rep. 2015, 5, 1-15. [CrossRef] [PubMed]

120. Chang, T.; Trench, D.; Putnam, J.; Stenzel, M.H.; Lord, M.S. Curcumin-Loading-Dependent Stability of PEGMEMA-Based Micelles Affects Endocytosis and Exocytosis in Colon Carcinoma Cells. Mol. Pharm. 2016, 13, 924-932. [CrossRef]

121. Madhusudana Rao, K.; Krishna Rao, K.S.V.; Ramanjaneyulu, G.; Ha, C.S. Curcumin encapsulated pH sensitive gelatin based interpenetrating polymeric network nanogels for anti cancer drug delivery. Int. J. Pharm. 2015, 478, 788-795. [CrossRef]

122. Seok, H.Y.; Sanoj Rejinold, N.; Lekshmi, K.M.; Cherukula, K.; Park, I.K.; Kim, Y.C. CD44 targeting biocompatible and biodegradable hyaluronic acid cross-linked zein nanogels for curcumin delivery to cancer cells: In vitro and in vivo evaluation. J. Control. Release 2018, 280, 20-30. [CrossRef]

123. Borah, P.K.; Das, A.S.; Mukhopadhyay, R.; Sarkar, A.; Duary, R.K. Macromolecular design of folic acid functionalized amylopectinalbumin core-shell nanogels for improved physiological stability and colon cancer cell targeted delivery of curcumin. J. Colloid Interface Sci. 2020, 580, 561-572. [CrossRef]

124. Abruzzo, A.; Zuccheri, G.; Belluti, F.; Provenzano, S.; Verardi, L.; Bigucci, F.; Cerchiara, T.; Luppi, B.; Calonghi, N. Chitosan nanoparticles for lipophilic anticancer drug delivery: Development, characterization and in vitro studies on HT29 cancer cells. Colloids Surf. B Biointerfaces 2016, 145, 362-372. [CrossRef]

125. Chirio, D.; Gallarate, M.; Peira, E.; Battaglia, L.; Serpe, L.; Trotta, M. Formulation of curcumin-loaded solid lipid nanoparticles produced by fatty acids coacervation technique. J. Microencapsul. 2011, 28, 537-548. [CrossRef]

126. Sanoj Rejinold, N.; Thomas, R.G.; Muthiah, M.; Chennazhi, K.P.; Manzoor, K.; Park, I.K.; Jeong, Y.Y.; Jayakumar, R. Anti-cancer, pharmacokinetics and tumor localization studies of $\mathrm{pH}-$, RF- and thermo-responsive nanoparticles. Int. J. Biol. Macromol. 2015, 74, 249-262. [CrossRef]

127. Alibolandi, M.; Hoseini, F.; Mohammadi, M.; Ramezani, P.; Einafshar, E.; Taghdisi, S.M.; Ramezani, M.; Abnous, K. Curcuminentrapped MUC-1 aptamer targeted dendrimer-gold hybrid nanostructure as a theranostic system for colon adenocarcinoma. Int. J. Pharm. 2018, 549, 67-75. [CrossRef] 
128. Chuah, L.H.; Roberts, C.J.; Billa, N.; Abdullah, S.; Rosli, R. Cellular uptake and anticancer effects of mucoadhesive curcumincontaining chitosan nanoparticles. Colloids Surf. B Biointerfaces 2014, 116, 228-236. [CrossRef]

129. Li, L.; Xiang, D.; Shigdar, S.; Yang, W.; Li, Q.; Lin, J.; Liu, K.; Duan, W. Epithelial cell adhesion molecule aptamer functionalized PLGA-lecithin-curcumin-PEG nanoparticles for targeted drug delivery to human colorectal adenocarcinoma cells. Int. J. Nanomed. 2014, 9, 1083-1096. [CrossRef]

130. Udompornmongkol, P.; Chiang, B.H. Curcumin-loaded polymeric nanoparticles for enhanced anti-colorectal cancer applications. J. Biomater. Appl. 2015, 30, 537-546. [CrossRef]

131. Chaurasia, S.; Chaubey, P.; Patel, R.R.; Kumar, N.; Mishra, B. Curcumin-polymeric nanoparticles against colon-26 tumor-bearing mice: Cytotoxicity, pharmacokinetic and anticancer efficacy studies. Drug Dev. Ind. Pharm. 2016, 42, 694-700. [CrossRef] [PubMed]

132. Xie, M.; Fan, D.; Li, Y.; He, X.; Chen, X.; Chen, Y.; Zhu, J.; Xu, G.; Wu, X.; Lan, P. Supercritical carbon dioxide-developed silk fibroin nanoplatform for smart colon cancer therapy. Int. J. Nanomed. 2017, 12, 7751-7761. [CrossRef] [PubMed]

133. Wadhwa, J.; Asthana, A.; Gupta, S.; Shilkari Asthana, G.; Singh, R. Development and optimization of polymeric self-emulsifying nanocapsules for localized drug delivery: Design of experiment approach. Sci. World J. 2014, 2014, 516069. [CrossRef] [PubMed]

134. Alkhader, E.; Billa, N.; Roberts, C.J. Mucoadhesive Chitosan-Pectinate Nanoparticles for the Delivery of Curcumin to the Colon AAPS PharmSciTech 2017, 18, 1009-1018. [CrossRef]

135. Alkhader, E.; Roberts, C.J.; Rosli, R.; Yuen, K.H.; Seow, E.K.; Lee, Y.Z.; Billa, N. Pharmacokinetic and anti-colon cancer properties of curcumin-containing chitosan-pectinate composite nanoparticles. J. Biomater. Sci. Polym. Ed. 2018, 29, 2281-2298. [CrossRef] [PubMed]

136. Sabra, R.; Billa, N.; Roberts, C.J. An augmented delivery of the anticancer agent, curcumin, to the colon. React. Funct. Polym. 2018, 123, 54-60. [CrossRef]

137. Sabra, R.; Roberts, C.J.; Billa, N. Courier properties of modified citrus pectinate-chitosan nanoparticles in colon delivery of curcumin. Colloid Interface Sci. Commun. 2019, 32, 100192. [CrossRef]

138. Mulik, R.S.; Mönkkönen, J.; Juvonen, R.O.; Mahadik, K.R.; Paradkar, A.R. Transferrin mediated solid lipid nanoparticles containing curcumin: Enhanced in vitro anticancer activity by induction of apoptosis. Int. J. Pharm. 2010, 398, 190-203. [CrossRef]

139. Sun, J.; Bi, C.; Chan, H.M.; Sun, S.; Zhang, Q.; Zheng, Y. Curcumin-loaded solid lipid nanoparticles have prolonged in vitro antitumour activity, cellular uptake and improved in vivo bioavailability. Colloids Surf. B Biointerfaces 2013, 111, 367-375. [CrossRef]

140. Wang, W.; Chen, T.; Xu, H.; Ren, B.; Cheng, X.; Qi, R.; Liu, H.; Wang, Y.; Yan, L.; Chen, S.; et al. Curcumin-loaded solid lipid nanoparticles enhanced anticancer efficiency in breast cancer. Molecules 2018, 23, 1578. [CrossRef]

141. Minafra, L.; Porcino, N.; Bravatà, V.; Gaglio, D.; Bonanomi, M.; Amore, E.; Cammarata, F.P.; Russo, G.; Militello, C.; Savoca, G.; et al. Radiosensitizing effect of curcumin-loaded lipid nanoparticles in breast cancer cells. Sci. Rep. 2019, 9, 1-16. [CrossRef]

142. Wei, X.; Senanayake, T.H.; Bohling, A.; Vinogradov, S. V. Targeted nanogel conjugate for improved stability and cellular permeability of curcumin: Synthesis, pharmacokinetics, and tumor growth inhibition. Mol. Pharm. 2014, 11, 3112-3122. [CrossRef] [PubMed]

143. Li, N.; Wang, Z.; Zhang, Y.; Zhang, K.; Xie, J.; Liu, Y.; Li, W.; Feng, N. Curcumin-loaded redox-responsive mesoporous silica nanoparticles for targeted breast cancer therapy. Artif. Cells Nanomed. Biotechnol. 2018, 46, 921-935. [CrossRef] [PubMed]

144. Kundu, M.; Sadhukhan, P.; Ghosh, N.; Chatterjee, S.; Manna, P.; Das, J.; Sil, P.C. pH-responsive and targeted delivery of curcumin via phenylboronic acid-functionalized ZnO nanoparticles for breast cancer therapy. J. Adv. Res. 2019, 18, 161-172. [CrossRef]

145. Song, W.; Su, X.; Gregory, D.A.; Li, W.; Cai, Z.; Zhao, X. Magnetic alginate/chitosan nanoparticles for targeted delivery of curcumin into human breast cancer cells. Nanomaterials 2018, 8, 907. [CrossRef]

146. Saleh, T.; Soudi, T.; Shojaosadati, S.A. Aptamer functionalized curcumin-loaded human serum albumin (HSA) nanoparticles for targeted delivery to HER-2 positive breast cancer cells. Int. J. Biol. Macromol. 2019, 130, 109-116. [CrossRef] [PubMed]

147. Matloubi, Z.; Hassan, Z. HSA-curcumin nanoparticles: A promising substitution for Curcumin as a Cancer chemoprevention and therapy. DARU J. Pharm. Sci. 2020, 28, 209-219. [CrossRef] [PubMed]

148. Ashkbar, A.; Rezaei, F.; Attari, F.; Ashkevarian, S. Treatment of breast cancer in vivo by dual photodynamic and photothermal approaches with the aid of curcumin photosensitizer and magnetic nanoparticles. Sci. Rep. 2020, 10, 1-12. [CrossRef]

149. Khan, M.N.; Haggag, Y.A.; Lane, M.E.; McCarron, P.A.; Tambuwala, M.M. Polymeric Nano-Encapsulation of Curcumin Enhances its Anti-Cancer Activity in Breast (MDA-MB231) and Lung (A549) Cancer Cells Through Reduction in Expression of HIF-1 $\alpha$ and Nuclear p65 (Rel A). Curr. Drug Deliv. 2018, 15, 286-295. [CrossRef] [PubMed]

150. Sampath, M.; Pichaimani, A.; Kumpati, P.; Sengottuvelan, B. The remarkable role of emulsifier and chitosan, dextran and PEG as capping agents in the enhanced delivery of curcumin by nanoparticles in breast cancer cells. Int. J. Biol. Macromol. 2020, 162, 748-761. [CrossRef]

151. Kumari, M.; Sharma, N.; Manchanda, R.; Gupta, N.; Syed, A.; Bahkali, A.H.; Nimesh, S. PGMD/curcumin nanoparticles for the treatment of breast cancer. Sci. Rep. 2021, 11,1-17. [CrossRef]

152. Jung, K.H.; Lee, J.H.; Park, J.W.; Kim, D.H.; Moon, S.H.; Cho, Y.S.; Lee, K.H. Targeted therapy of triple negative MDA-MB-468 breast cancer with curcumin delivered by epidermal growth factor-conjugated phospholipid nanoparticles. Oncol. Lett. 2018, 15, 9093-9100. [CrossRef] 
153. Mahalunkar, S.; Yadav, A.S.; Gorain, M.; Pawar, V.; Braathen, R.; Weiss, S.; Bogen, B.; Gosavi, S.W.; Kundu, G.C. Functional design of $\mathrm{pH}$-responsive folate-targeted polymer-coated gold nanoparticles for drug delivery and in vivo therapy in breast cancer. Int. J. Nanomed. 2019, 14, 8285-8302. [CrossRef]

154. Huang, C.; Chen, F.; Zhang, L.; Yang, Y.; Yang, X.; Pan, W. 99mTc radiolabeled HA/TPGS-based curcumin-loaded nanoparticle for breast cancer synergistic theranostics: Design, in vitro and in vivo evaluation. Int. J. Nanomed. 2020, 15, 2987-2998. [CrossRef]

155. Setayesh, A.; Bagheri, F.; Boddohi, S. Self-assembled formation of chondroitin sulfate-based micellar nanogel for curcumin delivery to breast cancer cells. Int. J. Biol. Macromol. 2020, 161, 771-778. [CrossRef] [PubMed]

156. Yallapu, M.M.; Maher, D.M.; Sundram, V.; Bell, M.C.; Jaggi, M.; Chauhan, S.C. Curcumin induces chemo/radio-sensitization in ovarian cancer cells and curcumin nanoparticles inhibit ovarian cancer cell growth. J. Ovarian Res. 2010, 3, 1-12. [CrossRef]

157. Bondì, M.L.; Emma, M.R.; Botto, C.; Augello, G.; Azzolina, A.; Di Gaudio, F.; Craparo, E.F.; Cavallaro, G.; Bachvarov, D.; Cervello, M. Biocompatible Lipid Nanoparticles as Carriers to Improve Curcumin Efficacy in Ovarian Cancer Treatment. J. Agric. Food Chem. 2017, 65, 1342-1352. [CrossRef]

158. Duse, L.; Agel, M.R.; Pinnapireddy, S.R.; Schäfer, J.; Selo, M.A.; Ehrhardt, C.; Bakowsky, U. Photodynamic therapy of ovarian carcinoma cells with curcumin-loaded biodegradable polymeric nanoparticles. Pharmaceutics 2019, 11, 282. [CrossRef]

159. Chang, P.Y.; Peng, S.F.; Lee, C.Y.; Lu, C.C.; Tsai, S.C.; Shieh, T.M.; Wu, T.S.; Tu, M.G.; Chen, M.Y.; Yang, J.S. Curcumin-loaded nanoparticles induce apoptotic cell death through regulation of the function of MDR1 and reactive oxygen species in cisplatinresistant CAR human oral cancer cells. Int. J. Oncol. 2013, 43, 1141-1150. [CrossRef] [PubMed]

160. Singh, S.P.; Sharma, M.; Gupta, P.K. Enhancement of phototoxicity of curcumin in human oral cancer cells using silica nanoparticles as delivery vehicle. Lasers Med. Sci. 2014, 29, 645-652. [CrossRef] [PubMed]

161. Mazzarino, L.; Loch-Neckel, G.; Dos Santos Bubniak, L.; Mazzucco, S.; Santos-Silva, M.C.; Borsali, R.; Lemos-Senna, E. Curcuminloaded chitosan-coated nanoparticles as a new approach for the local treatment of oral cavity cancer. J. Nanosci. Nanotechnol. 2015, 15, 781-791. [CrossRef]

162. Pillai, G.R.; Srivastava, A.S.; Hassanein, T.I.; Chauhan, D.P.; Carrier, E. Induction of apoptosis in human lung cancer cells by curcumin. Cancer Lett. 2004, 208, 163-170. [CrossRef]

163. Saengkrit, N.; Saesoo, S.; Srinuanchai, W.; Phunpee, S.; Ruktanonchai, U.R. Influence of curcumin-loaded cationic liposome on anticancer activity for cervical cancer therapy. Colloids Surf. B Biointerfaces 2014, 114, 349-356. [CrossRef]

164. Sajomsang, W.; Gonil, P.; Saesoo, S.; Ruktanonchai, U.R.; Srinuanchai, W.; Puttipipatkhachorn, S. Synthesis and anticervical cancer activity of novel $\mathrm{pH}$ responsive micelles for oral curcumin delivery. Int. J. Pharm. 2014, 477, 261-272. [CrossRef]

165. Khan, M.A.; Zafaryab, M.; Mehdi, S.H.; Ahmad, I.; Rizvi, M.M.A. Characterization and anti-proliferative activity of curcumin loaded chitosan nanoparticles in cervical cancer. Int. J. Biol. Macromol. 2016, 93, 242-253. [CrossRef] [PubMed]

166. Zaman, M.S.; Chauhan, N.; Yallapu, M.M.; Gara, R.K.; Maher, D.M.; Kumari, S.; Sikander, M.; Khan, S.; Zafar, N.; Jaggi, M.; et al. Curcumin Nanoformulation for Cervical Cancer Treatment. Sci. Rep. 2016, 6, 1-14. [CrossRef]

167. Ahmadi, F.; Ghasemi-Kasman, M.; Ghasemi, S.; Tabari, M.G.; Pourbagher, R.; Kazemi, S.; Alinejad-Mir, A. Induction of apoptosis in HeLa cancer cells by an ultrasonic-mediated synthesis of curcumin-loaded chitosan-alginate-STPP nanoparticles. Int. J. Nanomed. 2017, 12, 8545-8556. [CrossRef] [PubMed]

168. Bai, F.; Diao, J.; Wang, Y.; Sun, S.; Zhang, H.; Liu, Y.; Wang, Y.; Cao, J. A New Water-Soluble Nanomicelle Formed through Self-Assembly of Pectin-Curcumin Conjugates: Preparation, Characterization, and Anticancer Activity Evaluation. J. Agric. Food Chem. 2017, 65, 6840-6847. [CrossRef] [PubMed]

169. Malekmohammadi, S.; Hadadzadeh, H.; Rezakhani, S.; Amirghofran, Z. Design and Synthesis of Gatekeeper Coated Dendritic Silica/Titania Mesoporous Nanoparticles with Sustained and Controlled Drug Release Properties for Targeted Synergetic Chemo-Sonodynamic Therapy. ACS Biomater. Sci. Eng. 2019, 5, 4405-4415. [CrossRef]

170. Wang, W.Y.; Cao, Y.X.; Zhou, X.; Wei, B. Delivery of folic acid-modified liposomal curcumin for targeted cervical carcinoma therapy. Drug Des. Devel. Ther. 2019, 13, 2205-2213. [CrossRef]

171. You, L.; Liu, X.; Fang, Z.; Xu, Q.; Zhang, Q. Synthesis of multifunctional Fe3O4@PLGA-PEG nano-niosomes as a targeting carrier for treatment of cervical cancer. Mater. Sci. Eng. C 2019, 94, 291-302. [CrossRef]

172. Dai, Y.; Jiang, Z.; Li, J.; Wang, M.; Liu, C.; Qi, W.; Su, R.; He, Z. Co-assembly of curcumin and a cystine bridged peptide to construct tumor-responsive nano-micelles for efficient chemotherapy. J. Mater. Chem. B 2020, 8, 1944-1951. [CrossRef]

173. Mohanty, C.; Acharya, S.; Mohanty, A.K.; Dilnawaz, F.; Sahoo, S.K. Curcumin-encapsulated MePEG/PCL diblock copolymeric micelles: A novel controlled delivery vehicle for cancer therapy. Nanomedicine 2010, 5, 433-449. [CrossRef]

174. Yallapu, M.M.; Ebeling, M.C.; Khan, S.; Sundram, V.; Chauhan, N.; Gupta, B.K.; Puumala, S.E.; Jaggi, M.; Chauhan, S.C. Novel curcumin-loaded magnetic nanoparticles for pancreatic cancer treatment. Mol. Cancer Ther. 2013, 12, 1471-1480. [CrossRef]

175. Pan, K.; Luo, Y.; Gan, Y.; Baek, S.J.; Zhong, Q. Soft Matter assembled casein nanoparticles for enhanced dispersibility and bioactivity +. Soft Matter 2014, 10, 6820-6830. [CrossRef]

176. Arya, G.; Das, M.; Sahoo, S.K. Biomedicine \& Pharmacotherapy Evaluation of curcumin loaded chitosan / PEG blended PLGA nanoparticles for e ff ective treatment of pancreatic cancer. Biomed. Pharmacother. 2018, 102, 555-566. [CrossRef]

177. Chirio, D.; Peira, E.; Sapino, S.; Dianzani, C.; Barge, A.; Muntoni, E.; Morel, S.; Gallarate, M. Stearoyl-Chitosan Coated Nanoparticles Obtained by Microemulsion Cold Dilution Technique. Int. J. Mol. Sci. 2018, 19, 3833. [CrossRef] [PubMed] 
178. Chirio, D.; Peira, E.; Dianzani, C.; Muntoni, E.; Gigliotti, C.L.; Ferrara, B.; Sapino, S.; Chindamo, G.; Gallarate, M. Development of Solid Lipid Nanoparticles by Cold Dilution of Microemulsions: Curcumin Loading. Preliminary In Vitro Studies, and Biodistribution. Nanomaterials 2019, 9, 230. [CrossRef]

179. Wong, K.E.; Ngai, S.C.; Chan, K.; Lee, L.; Chan, K. Curcumin Nanoformulations for Colorectal Cancer: A Review. Front. Pharmacol. 2019, 10, 152. [CrossRef]

180. Hong, Y.; Che, S.; Hui, B.; Yang, Y.; Wang, X.; Zhang, X.; Qiang, Y.; Ma, H. Lung cancer therapy using doxorubicin and curcumin combination: Targeted prodrug based, pH sensitive nanomedicine. Biomed. Pharmacother. 2019, 112, 108614. [CrossRef]

181. Alemi, A.; Zavar Reza, J.; Haghiralsadat, F.; Zarei Jaliani, H.; Haghi Karamallah, M.; Hosseini, S.A.; Haghi Karamallah, S. Paclitaxel and curcumin coadministration in novel cationic PEGylated niosomal formulations exhibit enhanced synergistic antitumor efficacy. J. Nanobiotechnol. 2018, 16, 1-20. [CrossRef] [PubMed]

182. Vakilinezhad, M.A.; Amini, A.; Dara, T.; Alipour, S. Methotrexate and Curcumin co-encapsulated PLGA nanoparticles as a potential breast cancer therapeutic system: In vitro and in vivo evaluation. Colloids Surf. B Biointerfaces 2019, $184,110515$. [CrossRef] [PubMed]

183. Borah, A.; Pillai, S.C.; Rochani, A.K.; Palaninathan, V.; Nakajima, Y.; Maekawa, T.; Kumar, D.S. GANT61 and curcumin-loaded PLGA nanoparticles for GLI1 and PI3K/Akt-mediated inhibition in breast adenocarcinoma. Nanotechnology 2020, $31,185102$. [CrossRef] [PubMed]

184. Abd-Ellatef, G.E.F.; Gazzano, E.; Chirio, D.; Hamed, A.R.; Belisario, D.C.; Zuddas, C.; Peira, E.; Rolando, B.; Kopecka, J.; Marie, M.A.S.; et al. Curcumin-loaded solid lipid nanoparticles bypass p-glycoprotein mediated doxorubicin resistance in triple negative breast cancer cells. Pharmaceutics 2020, 12, 96. [CrossRef]

185. Yan, J.; Wang, Y.; Zhang, X.; Liu, S.; Tian, C.; Wang, H. Targeted nanomedicine for prostate cancer therapy: Docetaxel and curcumin co-encapsulated lipid-polymer hybrid nanoparticles for the enhanced anti-tumor activity in vitro and in vivo. Drug Deliv. 2016, 23, 1757-1762. [CrossRef]

186. Chen, Y.; Deng, Y.; Zhu, C.; Xiang, C. Anti prostate cancer therapy: Aptamer-functionalized, curcumin and cabazitaxel codelivered, tumor targeted lipid-polymer hybrid nanoparticles. Biomed. Pharmacother. 2020, 127, 110181. [CrossRef] [PubMed]

187. Li, L.; Ahmed, B.; Mehta, K.; Kurzrock, R. Liposomal curcumin with and without oxaliplatin: Effects on cell growth, apoptosis, and angiogenesis in colorectal cancer. Mol. Cancer Ther. 2007, 6, 1276-1282. [CrossRef] [PubMed]

188. Anitha, A.; Sreeranganathan, M.; Chennazhi, K.P.; Lakshmanan, V.K.; Jayakumar, R. In vitro combinatorial anticancer effects of 5-fluorouracil and curcumin loaded N,O-carboxymethyl chitosan nanoparticles toward colon cancer and in vivo pharmacokinetic studies. Eur. J. Pharm. Biopharm. 2014, 88, 238-251. [CrossRef]

189. Xiao, B.; Si, X.; Han, M.K.; Viennois, E.; Zhang, M.; Merlin, D. cationic polymeric nanoparticles for synergistic colon cancer combination chemotherapy. J. Mater. Chem. B 2015. [CrossRef]

190. Xiao, B.; Han, M.K.; Viennois, E.; Wang, L.; Zhang, M.; Si, X.; Merlin, D. Hyaluronic acid-functionalized polymeric nanoparticles for colon cancer-targeted combination chemotherapy. Nanoscale 2015, 7, 17745-17755. [CrossRef] [PubMed]

191. Lotfi-Attari, J.; Pilehvar-Soltanahmadi, Y.; Dadashpour, M.; Alipour, S.; Farajzadeh, R.; Javidfar, S.; Zarghami, N. Co-Delivery of Curcumin and Chrysin by Polymeric Nanoparticles Inhibit Synergistically Growth and hTERT Gene Expression in Human Colorectal Cancer Cells. Nutr. Cancer 2017, 69, 1290-1299. [CrossRef] [PubMed]

192. Tefas, L.R.; Sylvester, B.; Tomuta, I.; Sesarman, A.; Licarete, E.; Banciu, M.; Porfire, A. Development of antiproliferative longcirculating liposomes co-encapsulating doxorubicin and curcumin, through the use of a quality-by-design approach. Drug Des. Devel. Ther. 2017, 11, 1605-1621. [CrossRef]

193. Sesarman, A.; Tefas, L.; Sylvester, B.; Licarete, E.; Rauca, V.; Luput, L.; Patras, L.; Banciu, M.; Porfire, A. Anti-angiogenic and anti-inflammatory effects of long-circulating liposomes co-encapsulating curcumin and doxorubicin on C26 murine colon cancer cells. Pharmacol. Rep. 2018, 70, 331-339. [CrossRef]

194. Sabra, R.; Billa, N.; Roberts, C.J. Cetuximab-conjugated chitosan-pectinate (modified) composite nanoparticles for targeting colon cancer. Int. J. Pharm. 2019, 572, 118775. [CrossRef]

195. Kanai, M.; Imaizumi, A.; Otsuka, Y.; Sasaki, H.; Hashiguchi, M.; Tsujiko, K.; Matsumoto, S.; Ishiguro, H.; Chiba, T. Dose-escalation and pharmacokinetic study of nanoparticle curcumin, a potential anticancer agent with improved bioavailability, in healthy human volunteers. Cancer Chemother. Pharmacol. 2012, 69, 65-70. [CrossRef] [PubMed]

196. Storka, A.; Vcelar, B.; Klickovic, U.; Gouya, G.; Weisshaar, S.; Aschauer, S.; Bolger, G.; Helson, L.; Wolzt, M. Safety, tolerability and pharmacokinetics of liposomal curcumin in healthy humans. Int. J. Clin. Pharmacol. Ther. 2015, 53, 54-65. [CrossRef] [PubMed]

197. Saadipoor, A.; Razzaghdoust, A.; Simforoosh, N.; Mahdavi, A.; Bakhshandeh, M.; Moghadam, M.; Abdollahi, H.; Mofid, B. Randomized, double-blind, placebo-controlled phase II trial of nanocurcumin in prostate cancer patients undergoing radiotherapy. Phyther. Res. 2019, 33, 370-378. [CrossRef] [PubMed] 